\title{
حكمة العمل المصرفي الإسلامي المبنيّ على نظام المشاركة
}

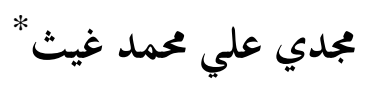

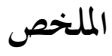

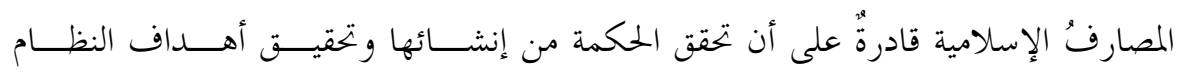

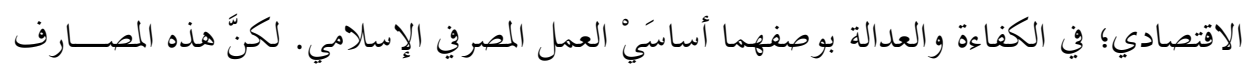

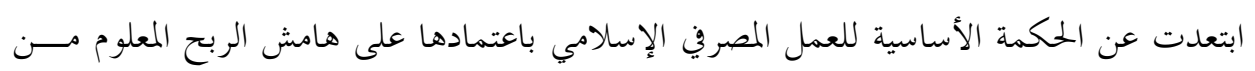

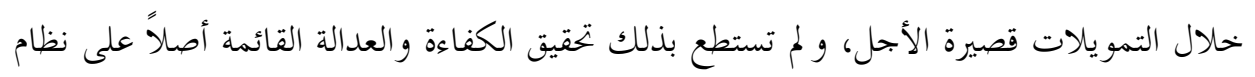

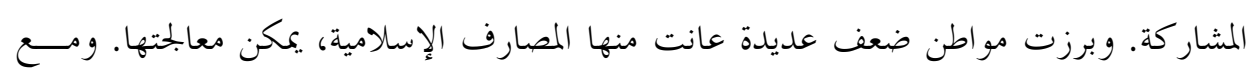
ذلك فثمة مواطن قوة كامنة في المصرفية الإسلامية، مكتنها من الصمود في وجه الأزمات.

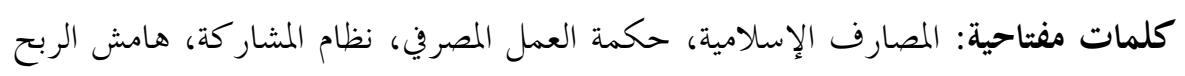
قصير المدى، النظام الاقتصادي، عناصر القوة، عناصر الضعف، المنتجات المالية المنمطة.

\section{Abstract}

Islamic banks should be able to achieve purposes of their establishment, i.e. building Islamic economic system, based on participation, and employs efficient financial products that would achieve efficacy and equity through certain mechanisms. Unfortunately Islamic banks moved away from those purposes by adopting assigned profit margin through short-term funding. Such problems can be addressed through certain suggested solutions. There are aspects of strength in Islamic banking as a result of their recognized roles of achieving considerable efficiency and justice, and resilience in the face of crises.

Keywords: Islamic banking, assigned profit margin, short term funding, system of participation, wisdom of Islamic banking, standardized financial products.

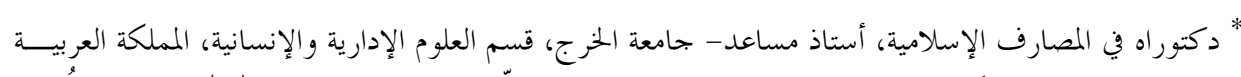

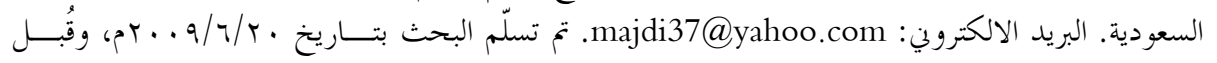

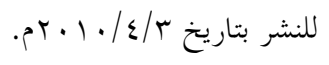




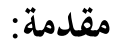

تُمثّل المصارفتُ الإسلامية في مناشطها الاستثمارية، أو خدماقا المصــــفية، لبنــةً

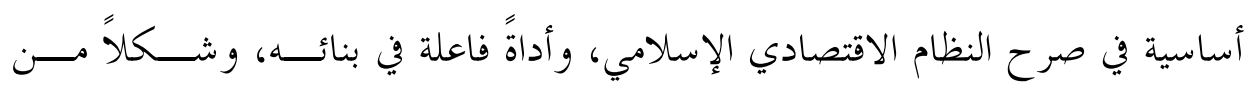

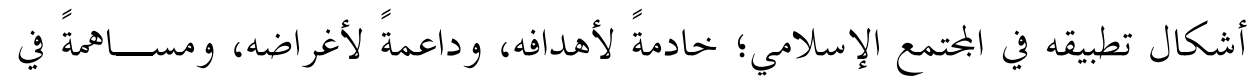

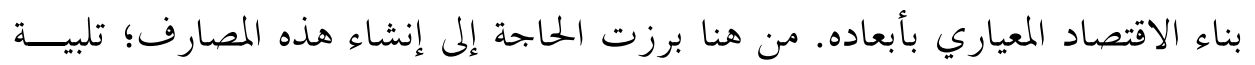
لآمال المسلمين وطموحاهم في سيادة التعامل المالي الإسلامي، وبعداً عن الربا، وربطاً

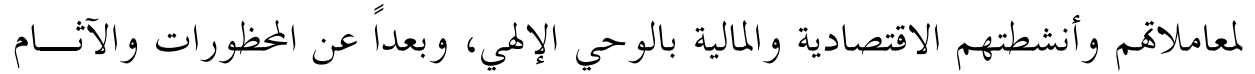

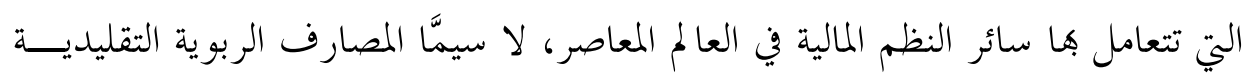

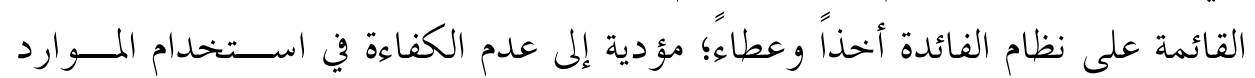
المالية، و كذلك عدم العدالة في توزيعها.

من هنا كانت أهمية البحث في حكمة العمل المصرفي الإسلامي واستجلاء الباعث

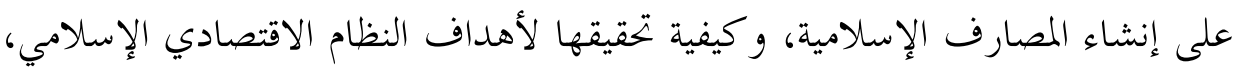

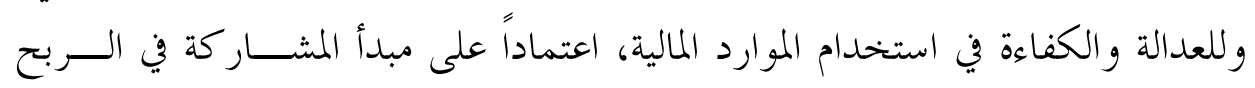
و الخنسارة، و ابتعاداً عن الظلم والاستغلال القائميْن على الربا و الفائدة. وتحقيقاً لهدف بتحلية الحكمة من العمل المصرفي الإسلامي، قُسِّم هذا البحســث إلى

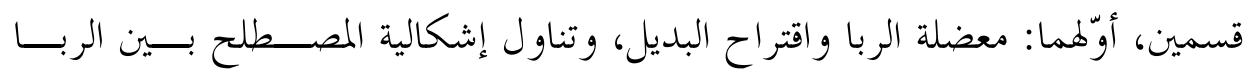
و الفائدة، واقتراح البديل للفائدة وللمصرف الربوي، وبيان خصائص ومميزات كل من

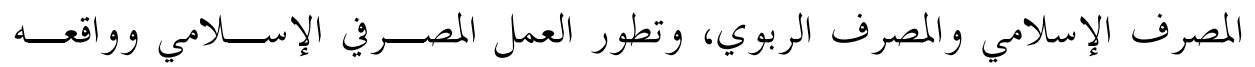

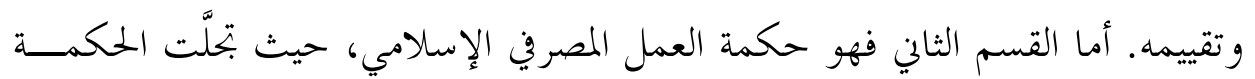

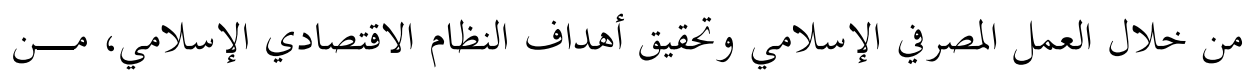

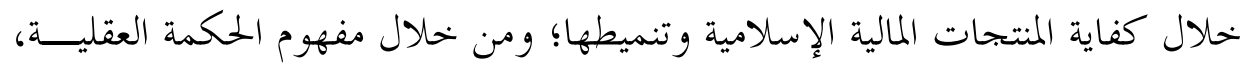

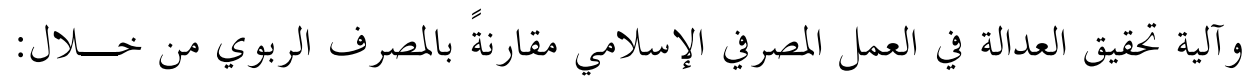

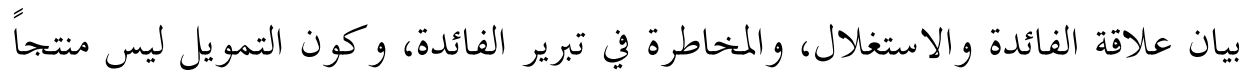
بذاته، ومسألة عدالة توزيع الدخل و الثروة. 
أما آلية تحقيق الكفاءة في العمل المصرفي الإسلامي فتجلت من خلال: الكفاءة في

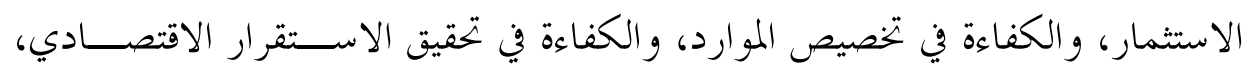
والكفاءة في تحقيق التنمية البشرية.

\section{القسم الأول: معضلة الربا واقتراح البديل وتقويمه}

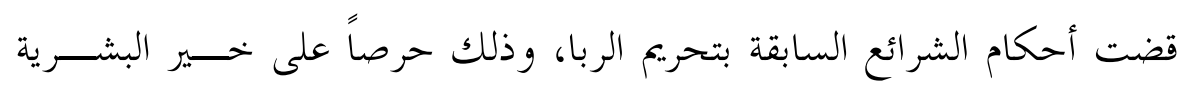

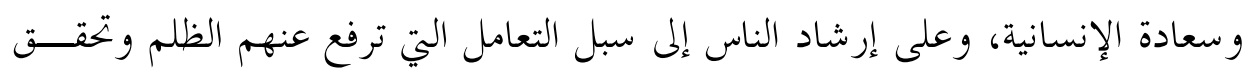

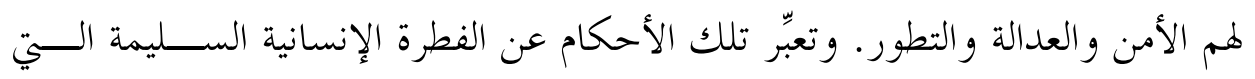

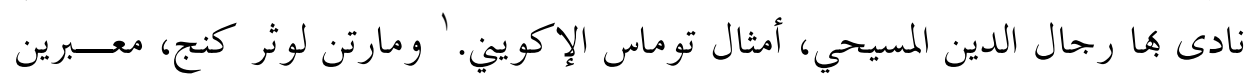
عن حس ديني قويم مطابق لتلك الفطرة السليمة.

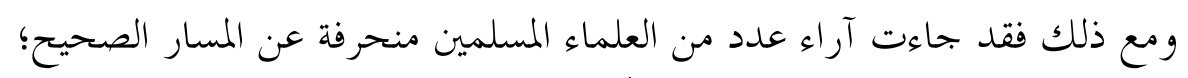

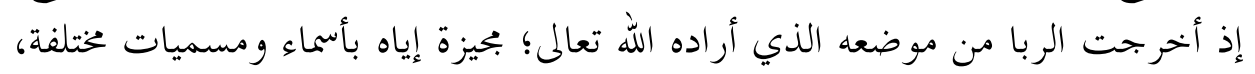

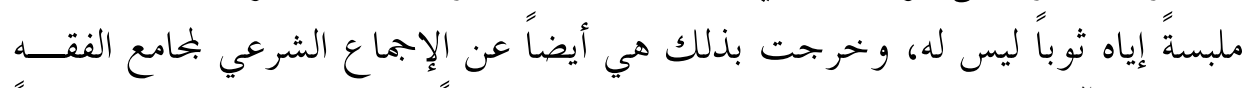

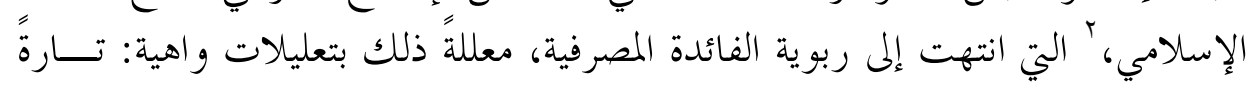

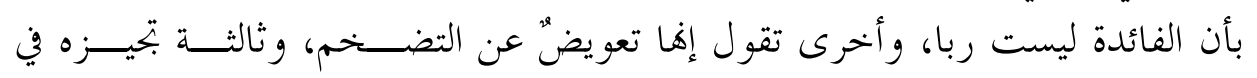

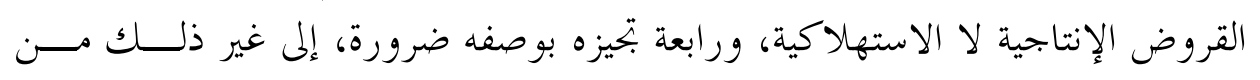

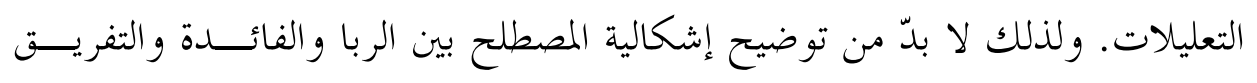
بينهما.

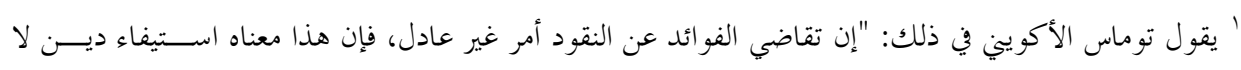

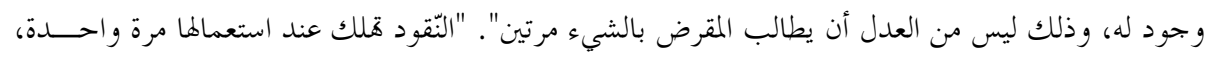

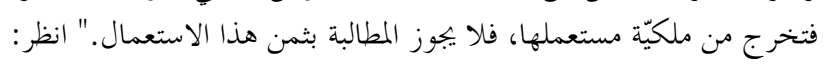

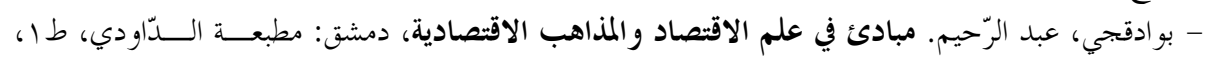

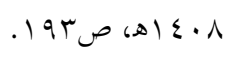
- النجار، أحمد. المدخل إلى النظرية الاقتصادية في المنهج الإسلامي، بــيروت: دار الفكـــ، طا، ـو9 (م)

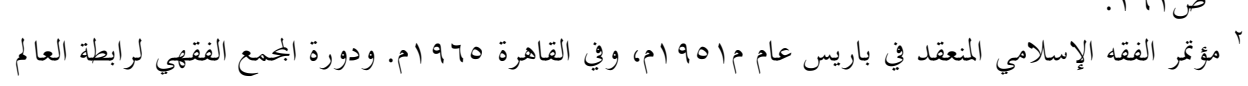

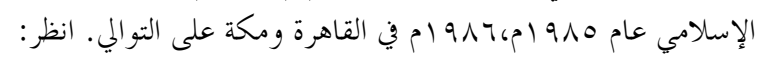

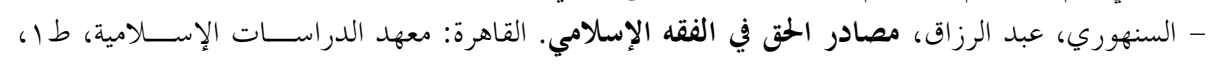

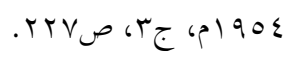




\section{أولاً: إشكالية المصطلح}

لقد تطورت صور المعاملات الربوية الحديثة، بعد نشأة المؤسسة المصرفية الربويـــة

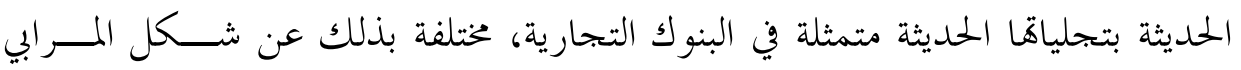

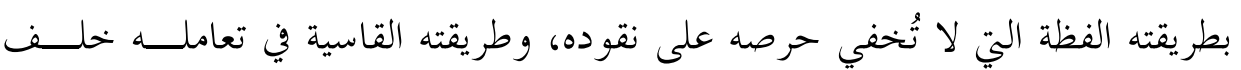

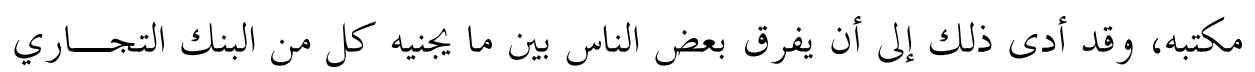
الحديث والمرابي، من مال نتيجة إقراضه لنقوده، و وجاء التفريق بين الربا و الفائدة. فهل

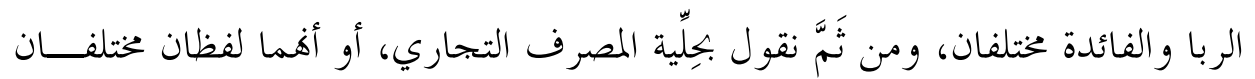
ولكنهما متطابقان في الجوهر؟ ولمن

\section{1 تعريف الربا وتقسيماته:}

لا نستطيع أن نقف على تعريف متفق عليه للربا عند الفقهاء القدامى و العلمـــاء المحدثين؛ ويعود ذلك بشكل أساس إلى الاختلاف البِّن فيما بينهم في تحديد عِلّة الربا، الأمر الذي يؤدي إلى الاختلاف فيما يدخل في الربا وما لا يدخل. ومن الأسباب التي

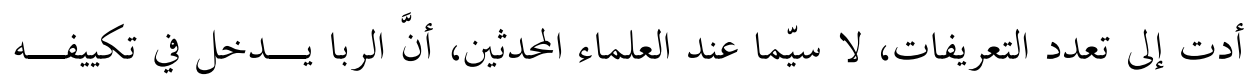

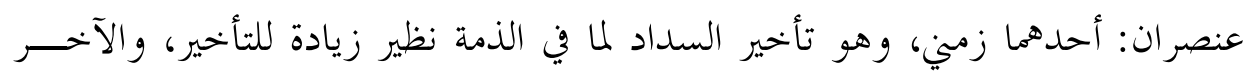
منفصل عن الزمن و التأخير، وهو المسمى ربا الفضل.

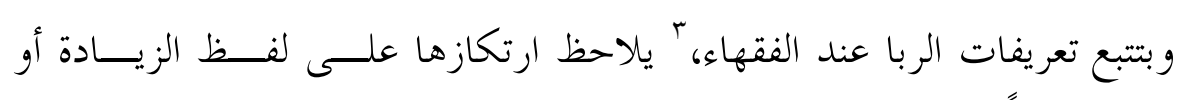

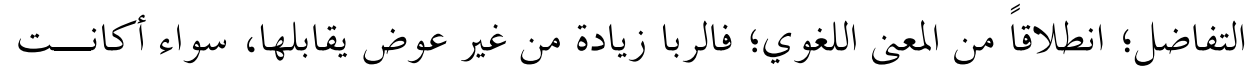

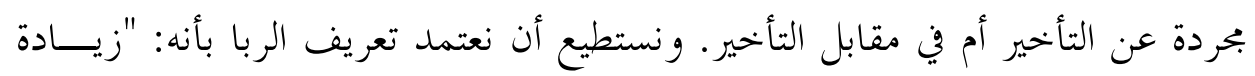

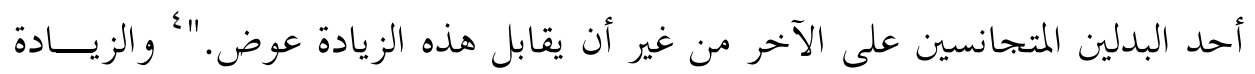

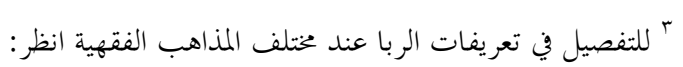

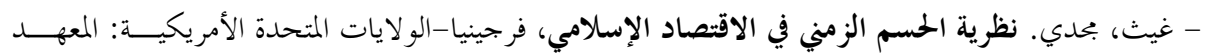

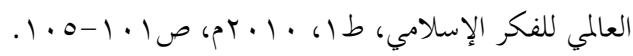

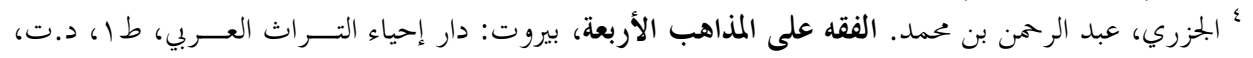


مقابل الزمن في ربا النَّساء، وربا النسيئة زيادة من غير عوض. وبتتبــع ع آراء العلمــــاء

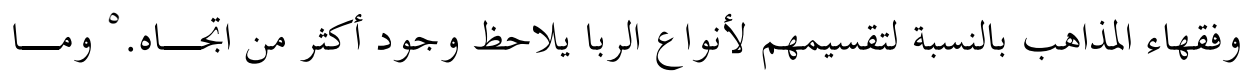
يهمنا في هذه الدراسة تقسيمات ربا الديون أو ربا النسيئة وهو ربا الجحاهلية، ويسمى:

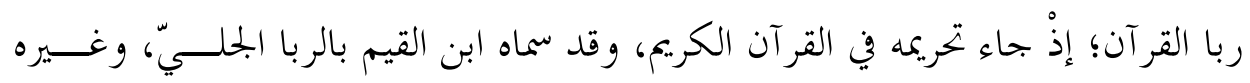

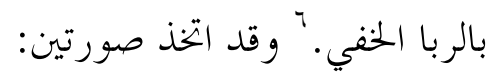

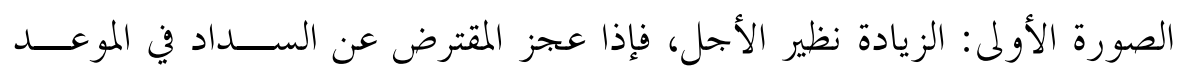
المحدد، زاد المرابي (المُقرض) في الدين نظير الأجل الجمديد.

الصورة الثانية: بيع السلعة بثمن مؤجل (ديناً)، فإذا حلَّ الأجل وعجز المشــتري

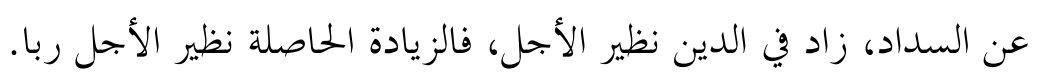

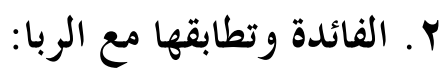

الفائدة لا تحتاج إلى بحث متخصص في تعريفها وتوضيحها؛ لشــــة وضـــوحها،

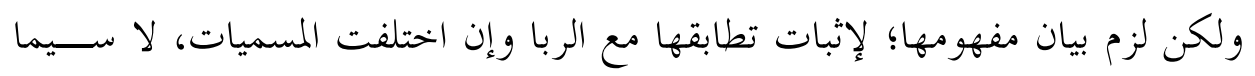

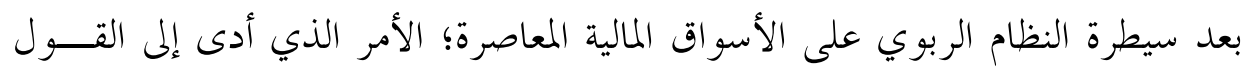

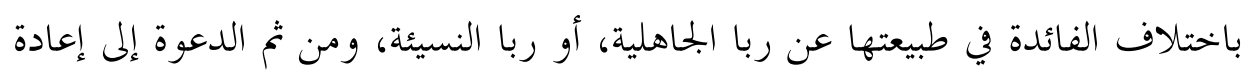
تفسير الربا.

مصطلح الفائدة، كما هو مستخحدم في بحال المعاملات المالية والنقدية في البلـــدان

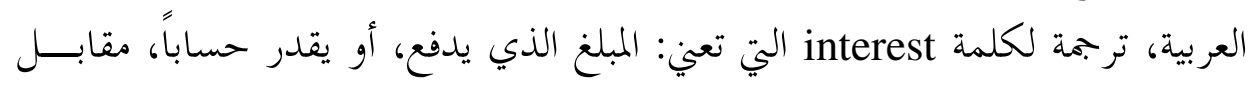

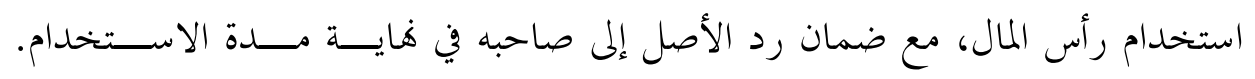

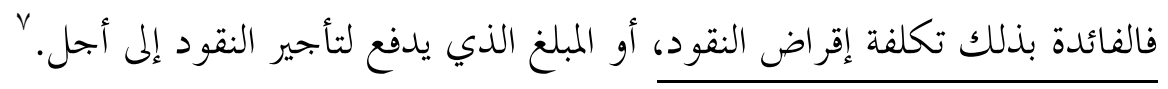

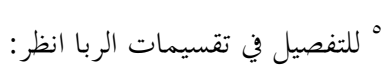

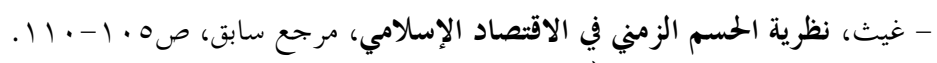

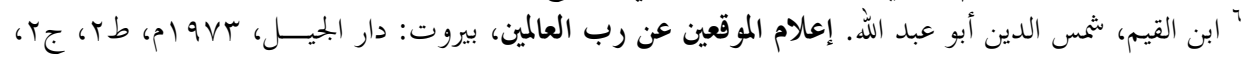

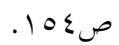
" يسري، عبد الرحمن. الربا والفائدة رد على المدافعين عن فو ائد البنك، الإسكندرية: الـــدار الجامعيـة، طا، 


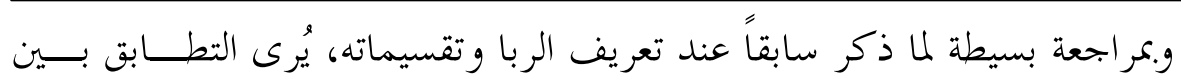

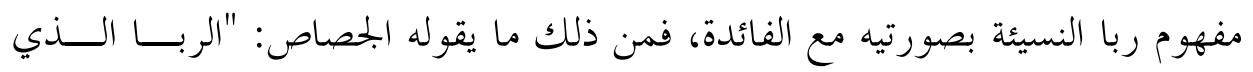

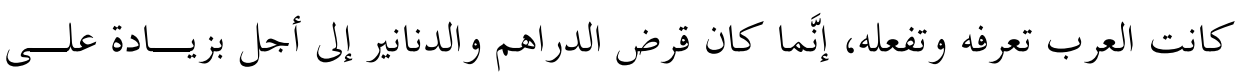

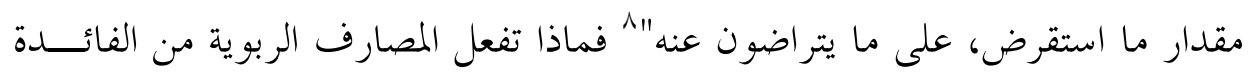
غير ذلك!

وللتطابق في الجوهر بين الربا و الفائدة لم تستطع الحجج المقدمة لصــالح تقــنين

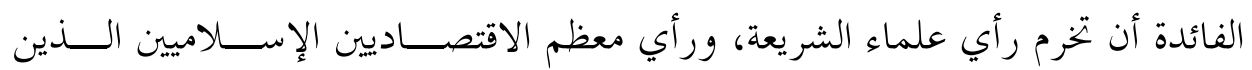

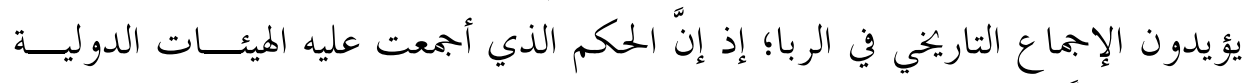

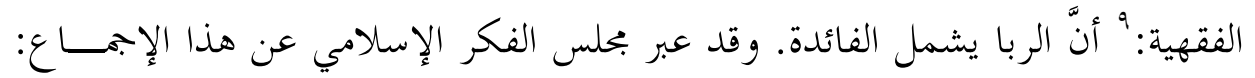

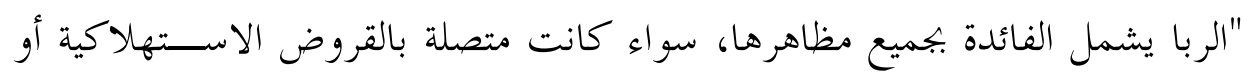

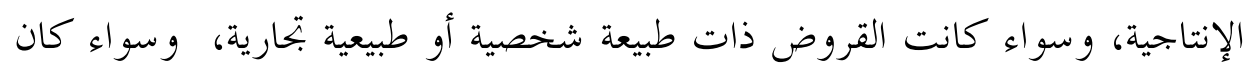

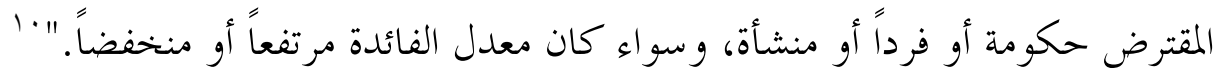

\section{ثانياً: اقتراح البديل للفائدة وللمصرف الربوي}

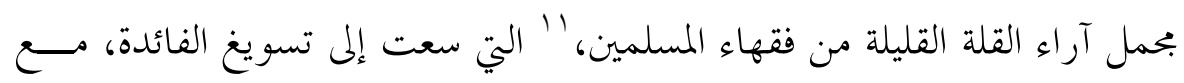

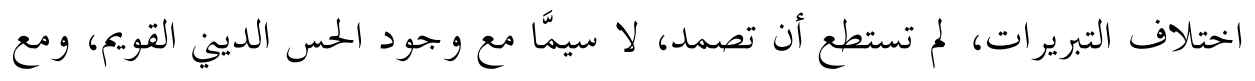

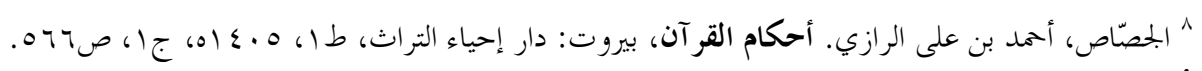

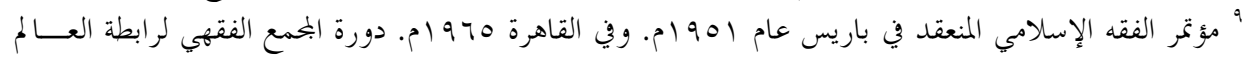

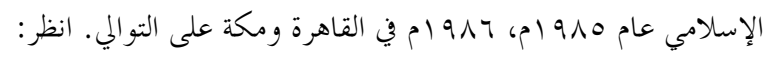

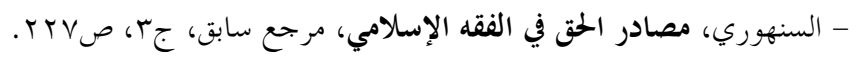

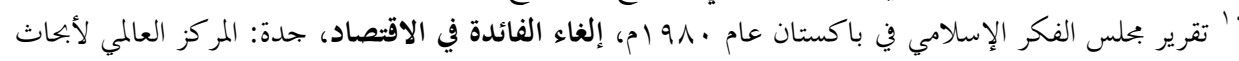

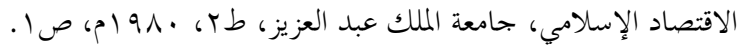

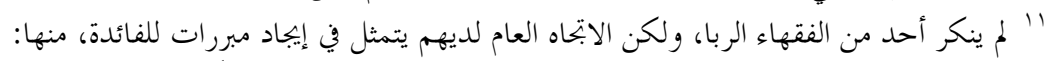

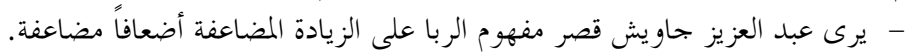

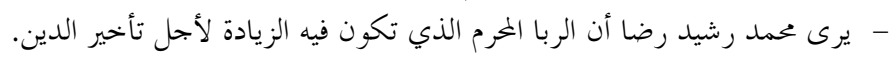

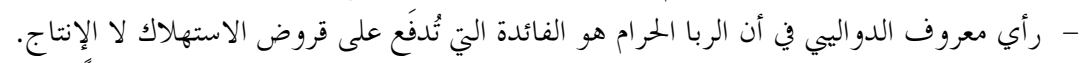

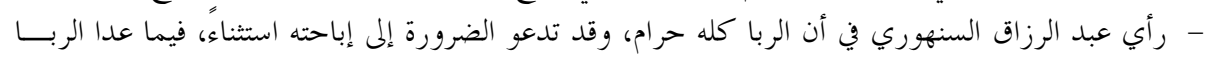

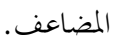
- رأي محمد سيد الطنطاوي في أن الفو ائد المصرفية بعضها رباً مؤ كد، وبعضها ربح محدد مسبقاً وحلال. 


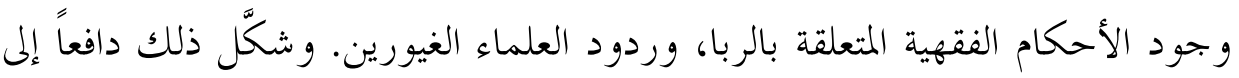

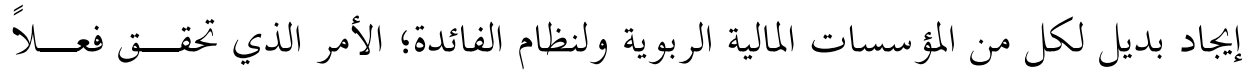

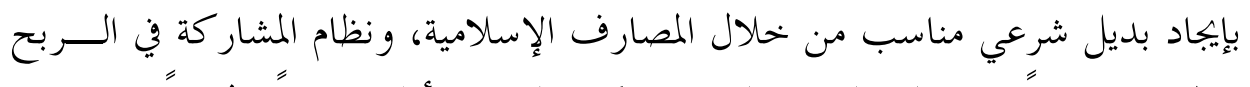

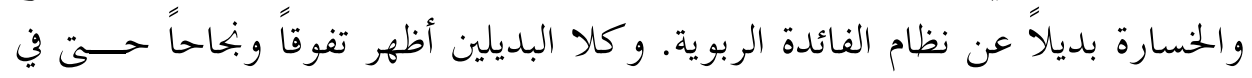
الدول الغربية الرأسمالية.

\section{ا ـ اقتراح البديل عن الفائدة:}

لم يخل الفكر الاقتصادي من بعض إشارات الإدانة للنظام المصرفي الربوي؛ بوصفة

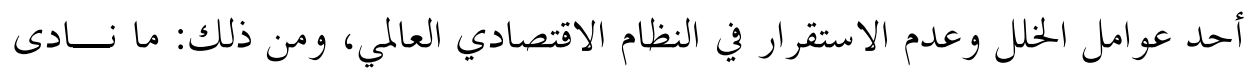

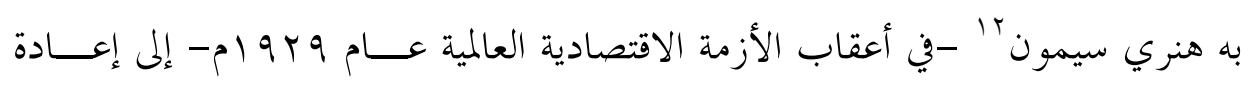
تنظيم النظام المصرفي المعاصر على أساس الفصل بين بنوك الودائع وبنوك الاســتثمار

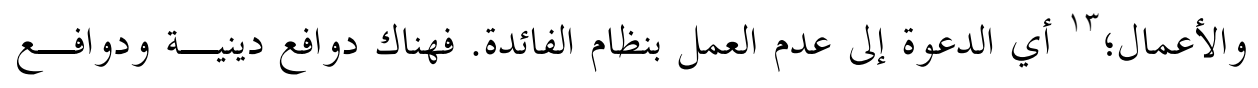

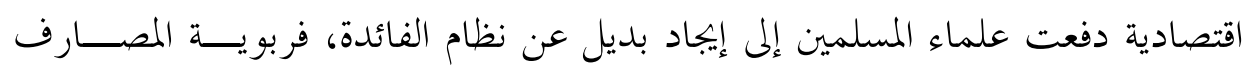

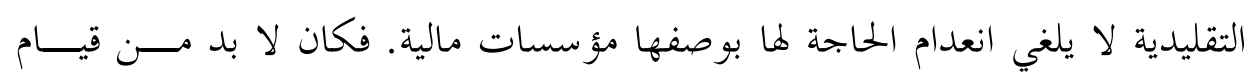

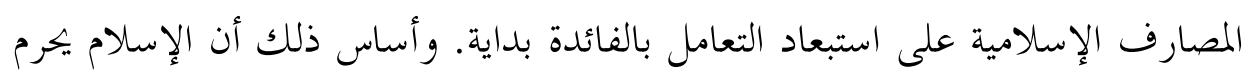

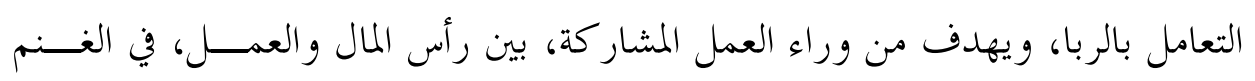

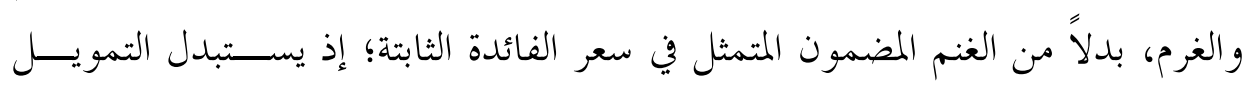

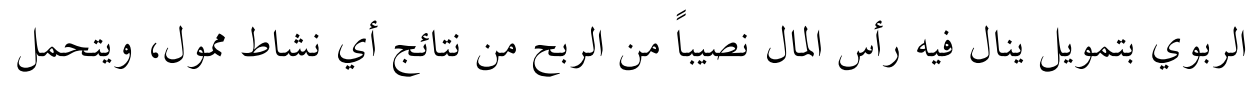
جانباً من الخسارة في حال تحقق خسائر.

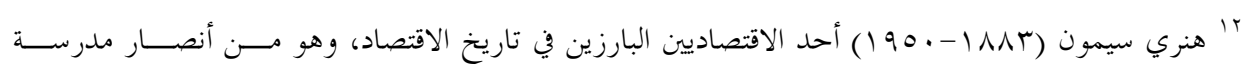

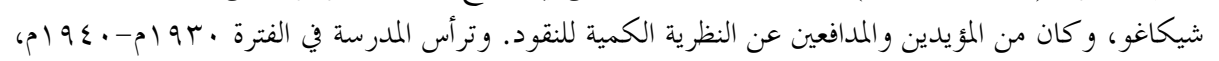

- Rockoff, Hugh. Henry Simons and the Quantity Theory of Money, New Brunswick: Department of Economics, Rutgers University,2000. p.1.

"' قلعاوي، غسان. المصارف الإسلامية ضرورة عصرية لماذا؟ وكيف؟، دمشـق: دار المكــبي، ط1، 991 (م، 


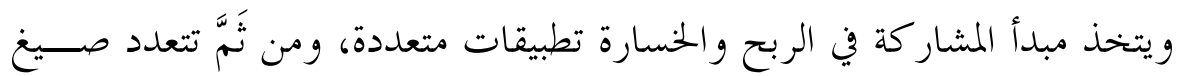

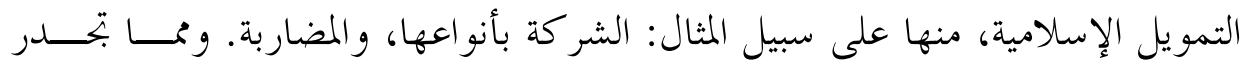

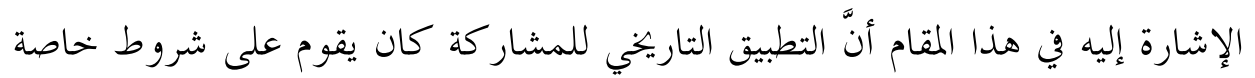

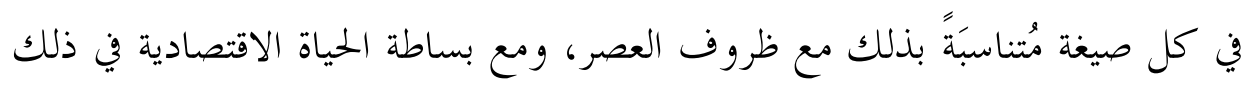

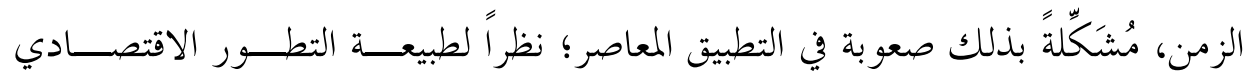

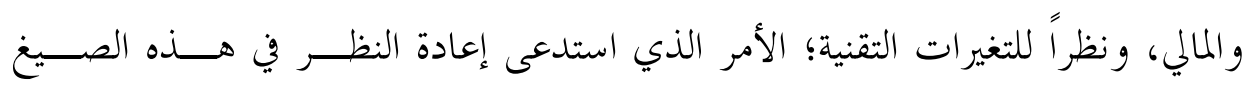

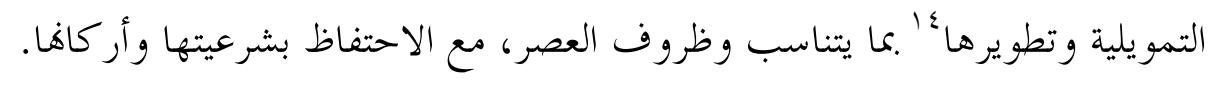

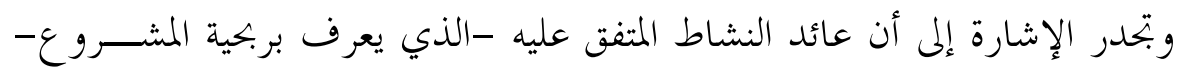

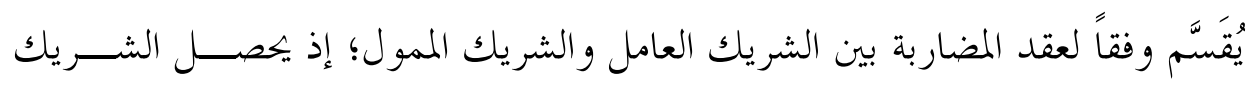

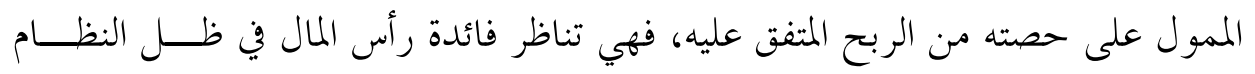

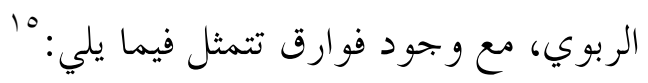

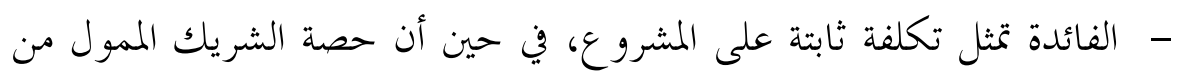
الأرباح تعد توزيعاً للنتائج.

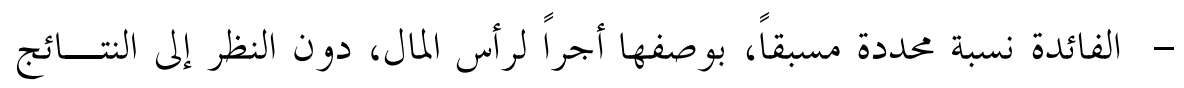

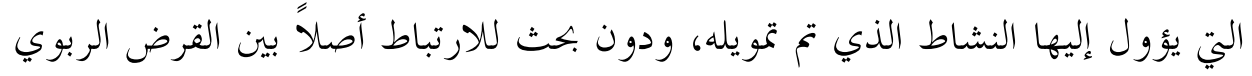

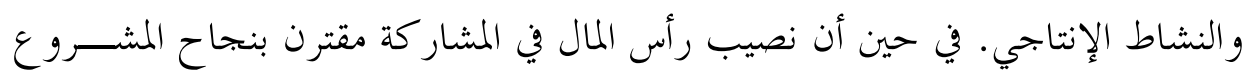

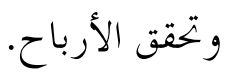

- تعمل المشاركة في الربح والخسارة على تحقيق العدالة والكفاءة الاقتصــادية،

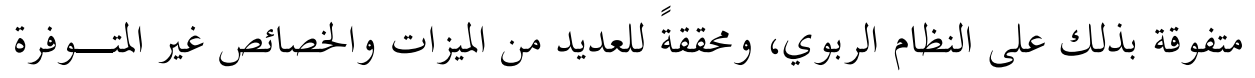
في النظام الربوي.

$$
\text { ؛' انظر تطوير الصيغ التمويلية الأساسية: }
$$

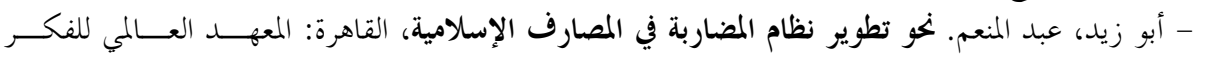

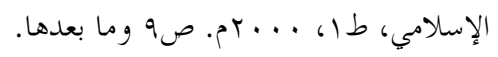

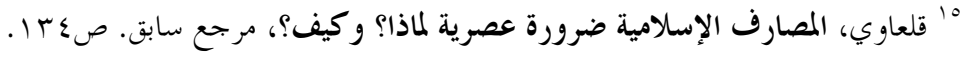




\section{r. اقتراح البديل عن المصرف الربوي:}

المصارف الإسلامية ثمرة من ثمرات الصحوة الإسلامية الرافضة لسيادة النمـــوذج المصرفي الغربي القائم على نظام الفائدة، ومع وجود البديل الشرعي للفائســدة بصــيغه

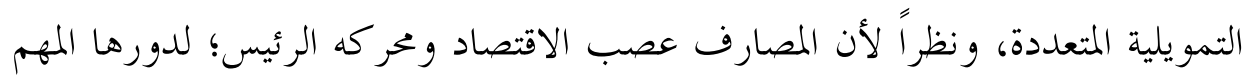
في حفظ الأموال وتحريكها وتنميتها، وتسهيل تداولها واستثمارها، كان لا بد من إيجاد

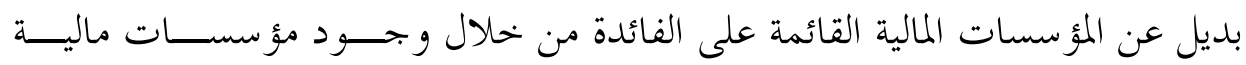
إسلامية تتعامل وفقاً لمبادئ الشريعة الإسلامية.

و كان للكتابات التنظيرية، وللجهود الفكرية لعدد من الكتُّاب -الـــذين قــدموا

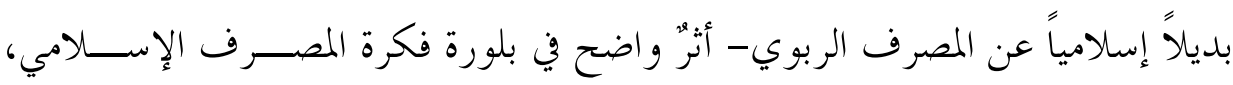

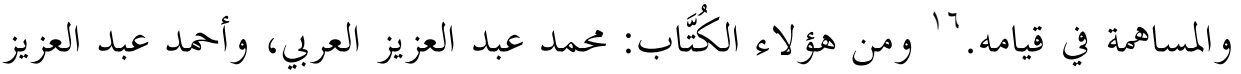
النجار، وعيسى عبده، ومحمد باقر الصدر، ومحمد بجاة الله صديقي، ومحمد عزيز. وقد

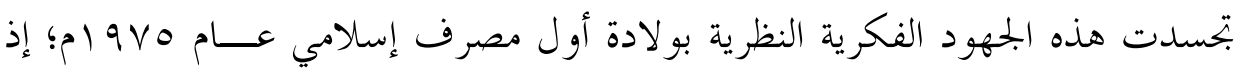
تنافس على شرف الرياده مصرفان، هما: بنك دبي الإسلامي، الذي يُعدّ مصدراً فكرياً لعدد من البنوك الإسلامية التي أسست بعده، و البنك الإسلامي للتنمية الذي فتح أبوابه

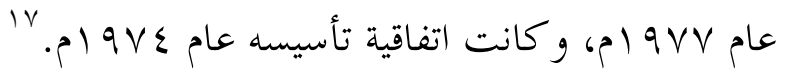
إنّ من سبق ذكرهم هم زبدة الآباء المؤسسين للمصرف الإســلامي؛ واسـتقر اء فكرهم يكشف لنا أن المصرف الإسلامي في نظرهم يتصف ربد بماء بلئي: أ. أساس عمل المصرف الإسالامي في نظر المؤسسين هو الشراكة والمضاربة، فهو

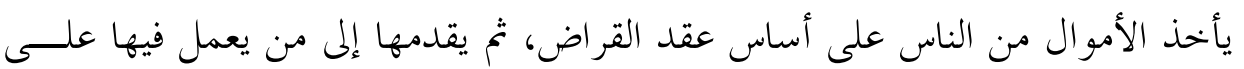
17 القرى، محمد علي. البنك الإسلامي بين فكر المؤسسين والو اقع المعاصر، جدة: منظمة المــؤتمر الإســلامي،

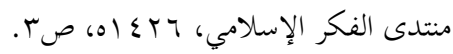

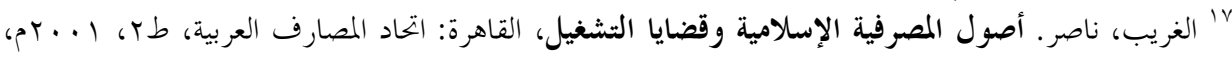


أساس الاشتراك في الربح والخخارة بعقود المضاربة والمشاركة وغيرها، وهناك من قال

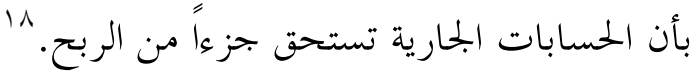

ب. "ليست غاية المصرف الإسلامي تقديم الحلال على الحرام في معاملات البنوك

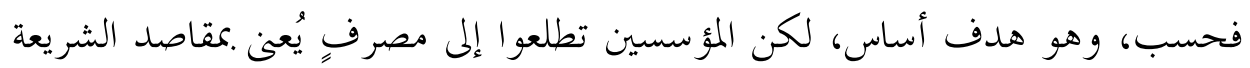

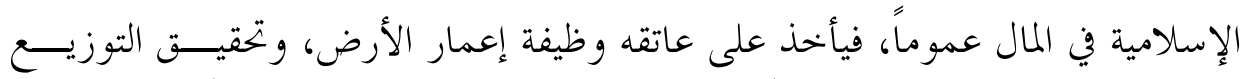

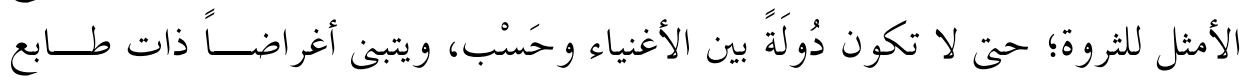
اجتماعي عام. "19. الاعنئ

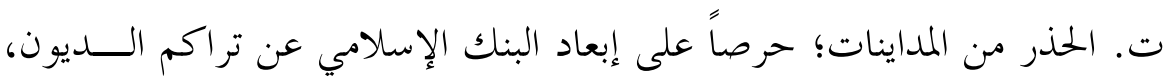

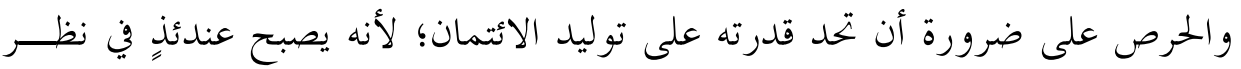

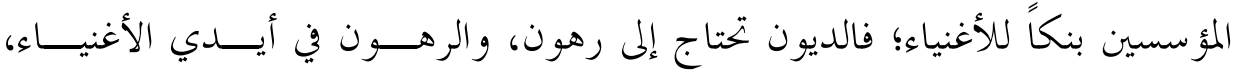

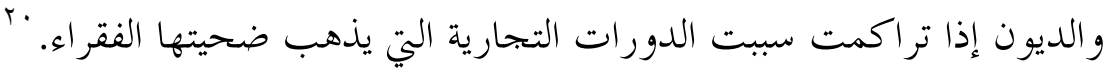
ث. وللمصرف الإسلامي عند المؤسسين وظائف اجتماعية مستمدة من كونــهـ

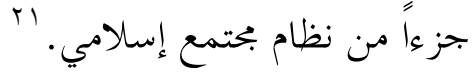

\section{ثالثاً: المصرف الإسلامي والمصرف الربوي خصائص وميزات}

بناءً على الجهود الفكرية -التي سبق ذكرها- قُدِّم المصرف الإسلامي بديلاً عــن

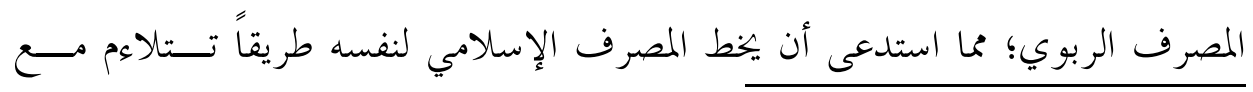

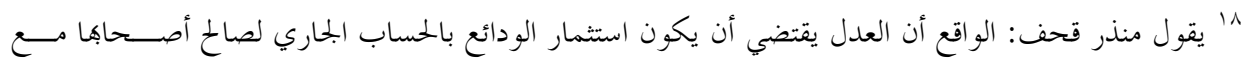

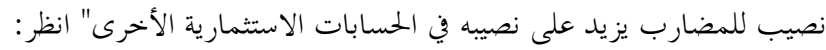

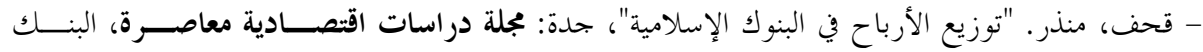

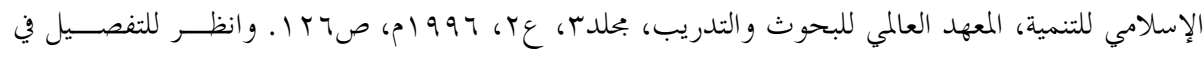

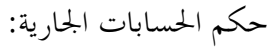

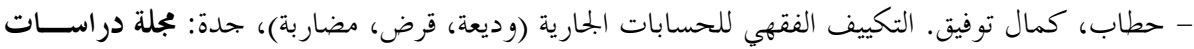

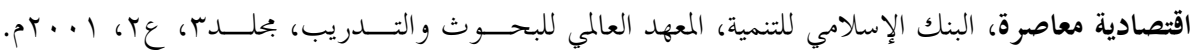
. ص ص إ ‘' القرى، محمد علي. البنك الإسلامي بين فكر المؤسسين والو اقع المعاصر، مرجع سابق، صَّ.

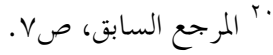
"r المرجع السابق، صرحابق، صل 
منظومته القيمية الإسلامية داخل الإطار الفقهي المالي الإسلامي؛ الأمر الـــذي أدى إلى

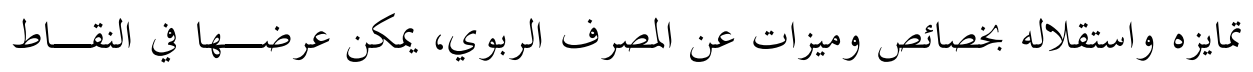
الآتية:

ا . من حيث ضمان الربح و الخسنارة أو عدم ضماهما: فكـثيرون لا يــــركون الفارق الأساس بين المصرف الإسلامي و المصرف الربوي، لا سيمَّا من حيث التعريف،

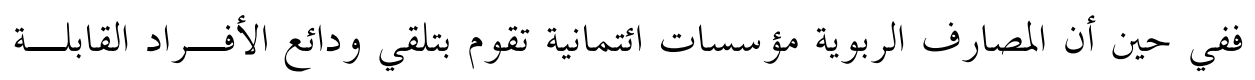

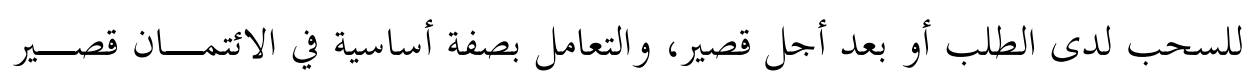

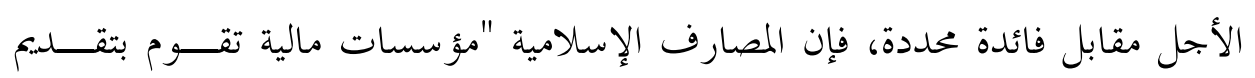

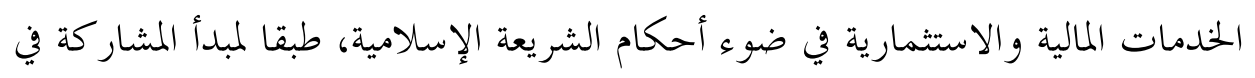
الربح والخسارة؛ إذ تعد قاعدة المشاركة في العمل المصرفي الإسلامي القاعدة الرئيســـة

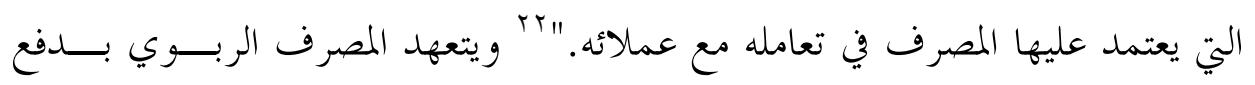

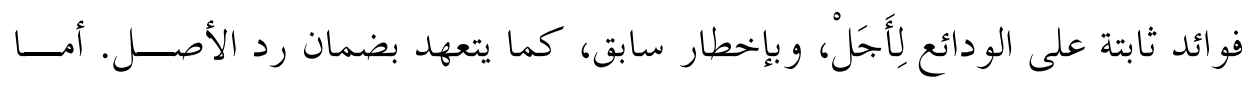

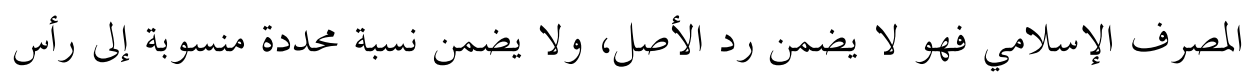

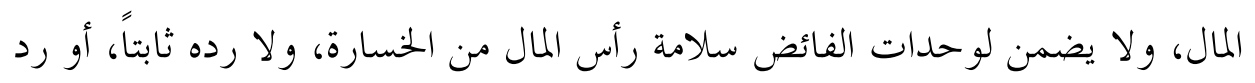

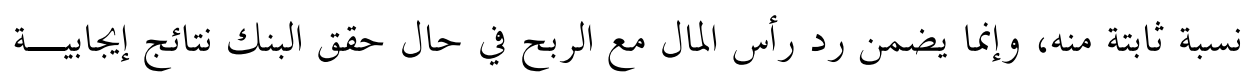

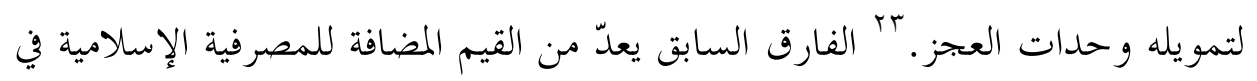

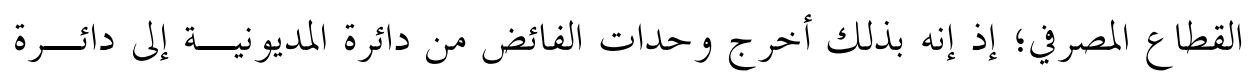
المشار كة و الفاعلية.

r. من حيث المتاجرة في الملكية والوساطة المالية: ؟ فالمصرف الربوي يقوم نطاق

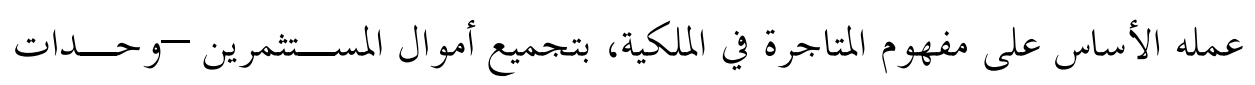

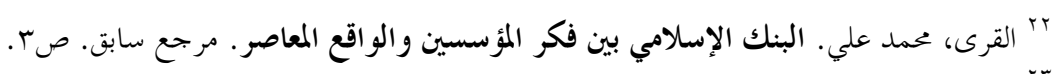

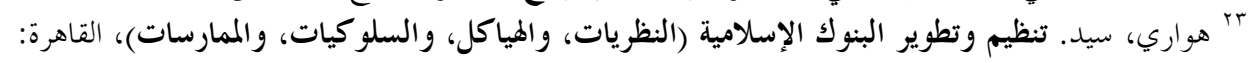

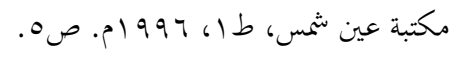

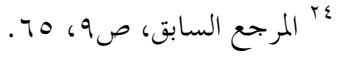




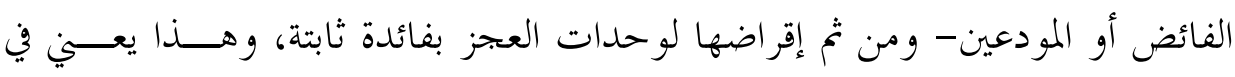
المحصلة أن المصرف الربوي وكيل عن المودعين في إقراض أمو الهم بفائدة ثابتة، ويتقاسم

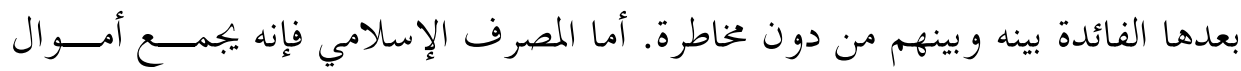

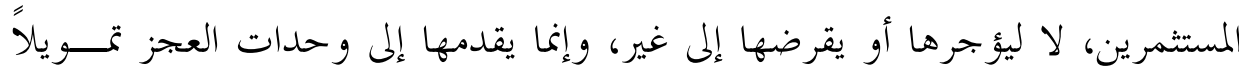
قائماً على مبدأ المشار كة في الربح والخسارة (و ساطة استثمارية).

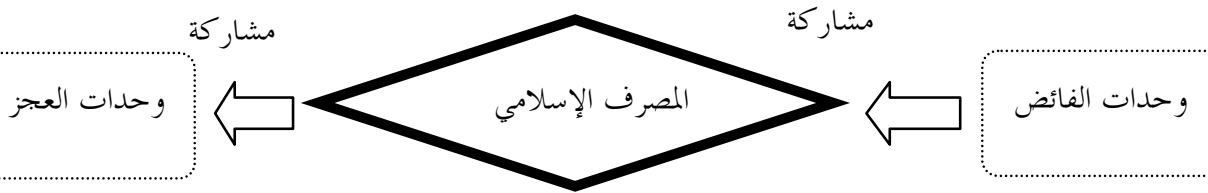

r. الفرق من حيث بحالات توظيف الأموال وصيغ التمويل: فالبديل الشرعي -

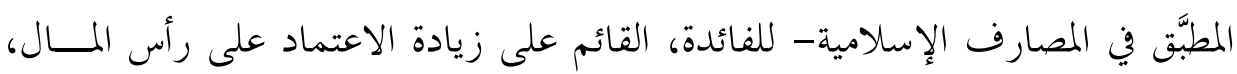

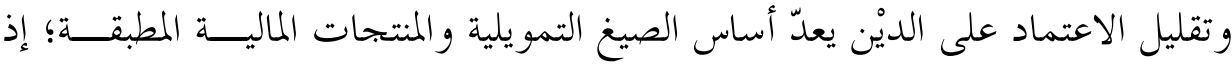
تتألف المنتجات المالية من بحموعة من الصيغ الأولية: كالمضاربة، والمشار كة. وبحموعة ولئية

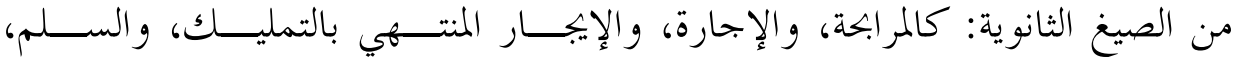

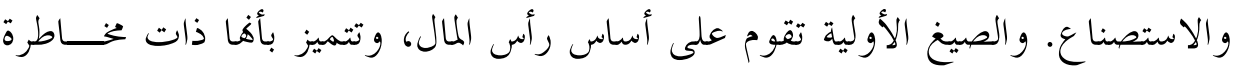

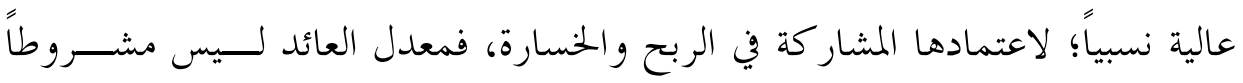

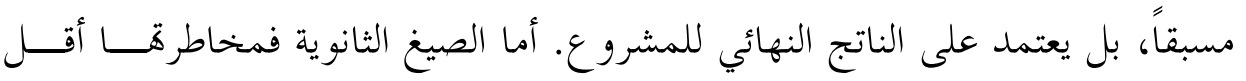

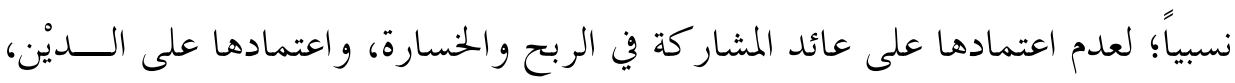
ومعدل العائد موجب ومحدد مسبقاً.

وعلى النقيض تماماً يلاحظ أن جزءاً كبيرًا من الأموال في المصارف الربوية يوجَّـــه.

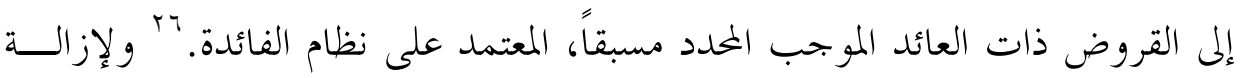

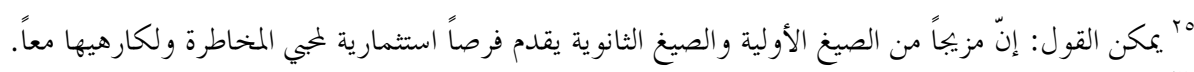

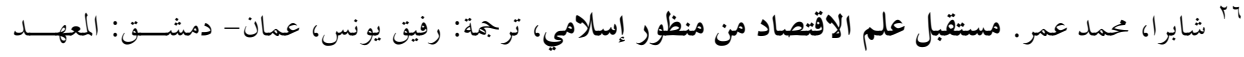

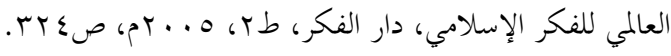


الالتباس الذي قد يختلط في الأذهان بين الصيغ الثانويـــة في المصـــارف الإســلامية،

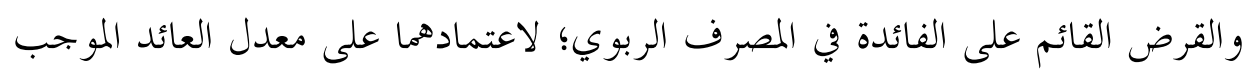
المحدد مسبقاً، كان لا بد من بيان الفرق الجوهري بينهما. فالصيغ الثانوية هي مبايعات ومؤاجرات (سلع مقابل نقد)، وليست صفقات إقراض و اقتر اض صريحة (نقد مقابــل

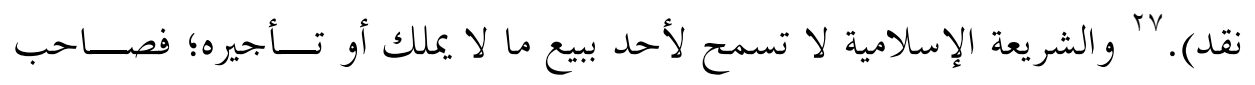

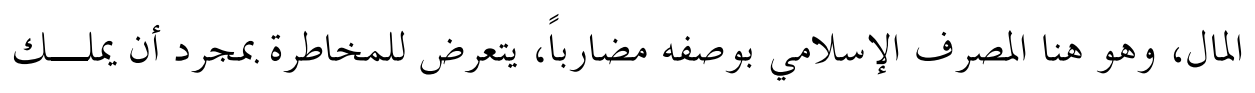

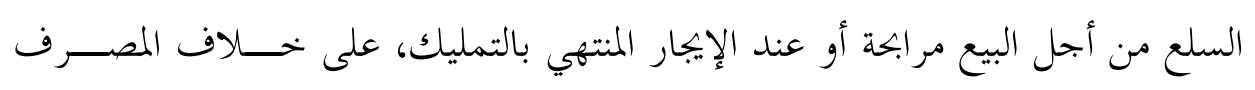

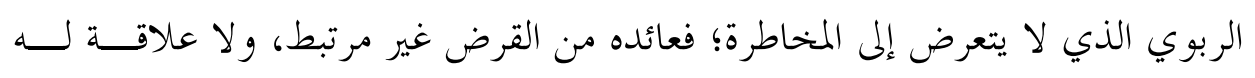
بنتيجة النشاط الإنتاجي الذي وظف القرض فيه، فهو غنم مضمون بلرحد سريان الزمن على التمكين من النقود(ربا النسيئة).

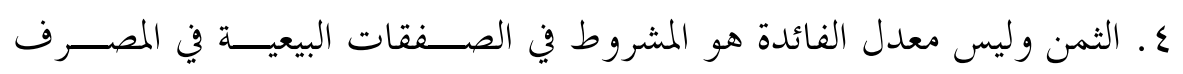

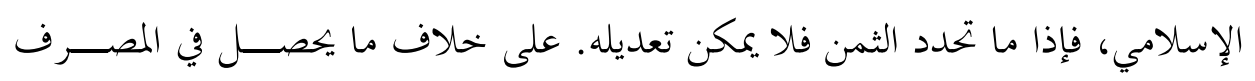

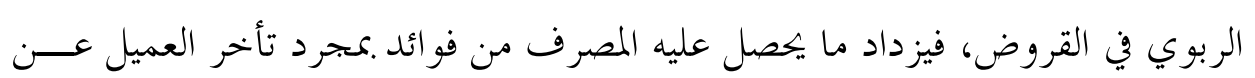
السداد وتحسب عليه الفو ائد المركبة بعد ذلك.

يلاحظ مما تقدم عند النظر إلى الصيغ التمويلية في المصرف الإســالامي -الأوليــة

و الثانوية- بالإضافة لتعددها أمام وحدات الفائض ووحدات العجز، فإِها تتمتع بالمرونة التي يمكنها تلبية رغبات العملاء المتنوعة، ولكافة القطاعات الاقتصادية، كما تتميز كل

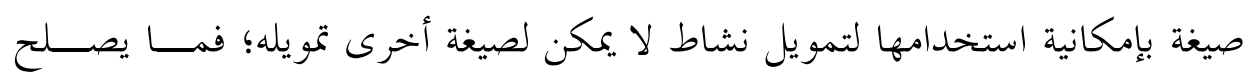

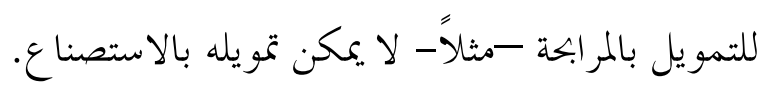

rv هواري، تنظيم وتطوير البنوك الإسلامية (النظريات، والهياكل، والسلوكيات، والممارسات)، مرجع سابق،

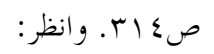

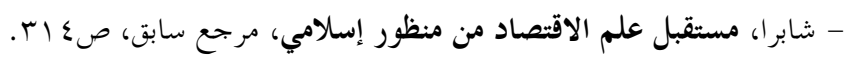

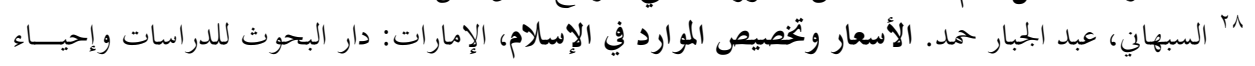

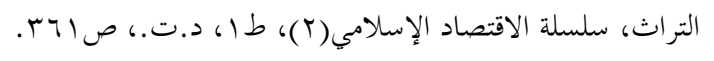




\section{رابعاً: العمل المصرفي الإسلامي (الواقع، والتطور، والتقويم)}

التحدي الكبير الذي واجه المصرف الإسلامي هو قدرته على تلبيـــة احتياجــــات

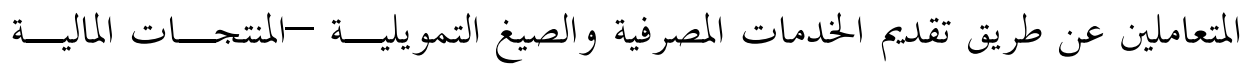

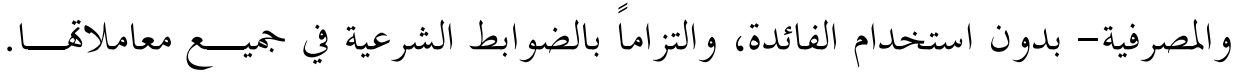
فكان هذا التحدي أهم عامل من عوامل تطور العمل المصرفي الإسلامي وبناحِِ. وقد تطورت أعمال المصارف الإسلامية تطوراً لم يتوقعه أحد، عندما بدأت أول تجربة لإنشاء بنك إسلامي عام وv ام. وطبقاً لآخر إحصائية صادرة عن البحلس العام

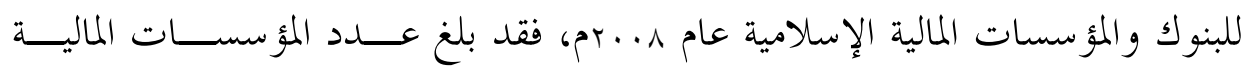

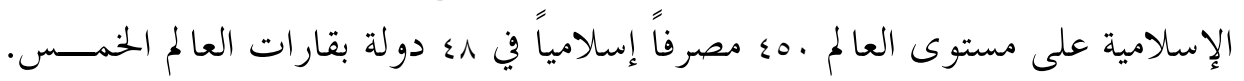

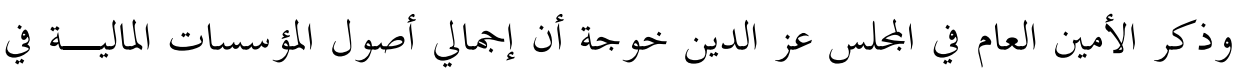

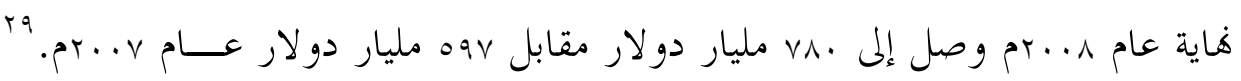
و بالنظر إلى التوزيع الجغرافي فإن منطقيت شرق آسيا توجد فيها قرابة نصف المؤسسات

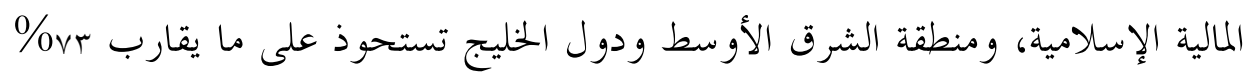
من النشاط المصرفي الإسلامي.

وهكذا أصبحت المؤسسات المالية الإسلامية حقيقة قائمة، وأنَّها وجدات لتبقـى،

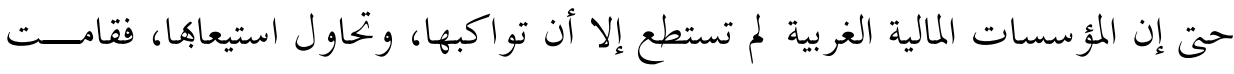

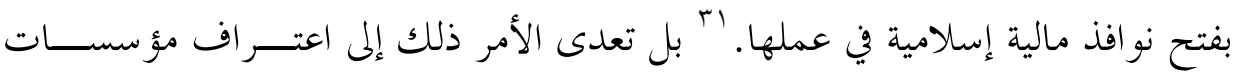

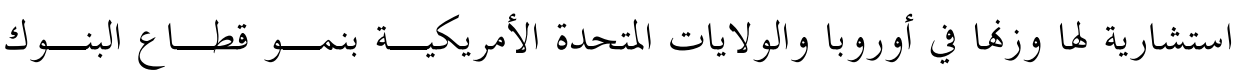

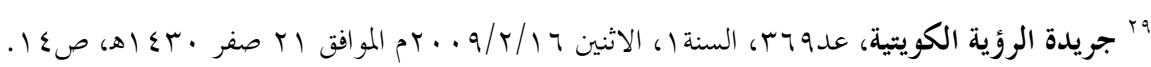
30 Jarhi, Mabid \& Iqbal, Munawar. Islamic Banking: Answers to some frequently asked questions, occasional paper, No. 4, IRTI, IDB, Jeddah, 2001.

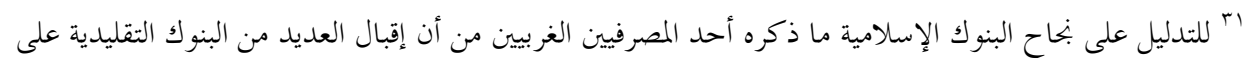

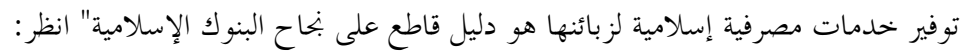

- Wilson, Rodney. Islamic Banking and Finance, in the Middle East and North Africa, Londres: Europe Publications. p.p32. 


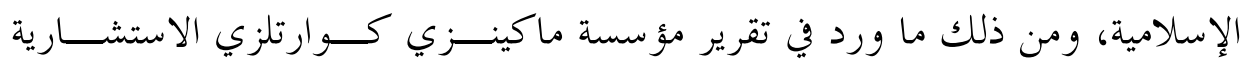

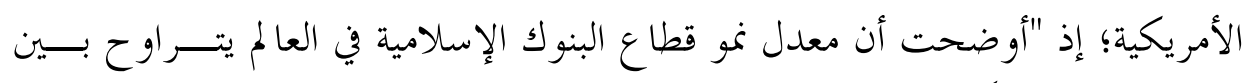

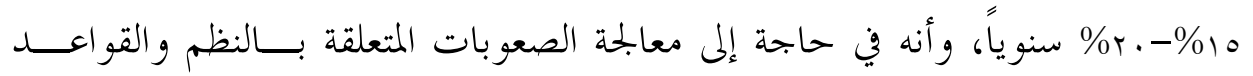
الحاكمة.

ومواكبة لتطور العمل المصرفي الإسلامي واستمراريته كان لا بدّ من إنشاء عـــدد

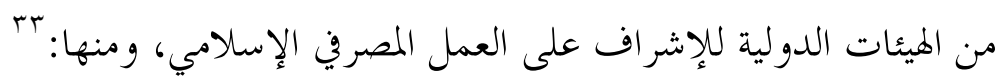
هيئة المحاسبة والمر اجعة للمؤسسات المالية الإسلامية (AAOIFI)، التي أنشئت

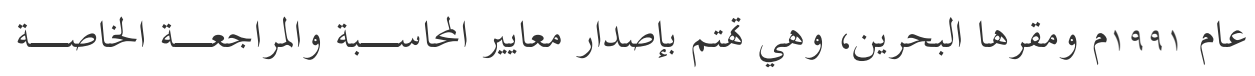
بالمصارف الإسلامية.

•الجحلس العام للبنوك و المؤسسات المالية والإسلامية (GCIBFI)، الذي أنشــــ عام ا...rم، ومقره البحرين، ويهتم بتوفير المعلومات عن الصناعة المصرفية الإسلامية، ونشر الوعي في العام، حول العمل المصري الإسلامي.

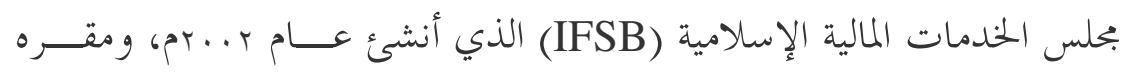

ماليزيا، وقد قام بتأسيسه العديد من البنوك المركزية ومؤسسات النقد في العالم، ومنها: مؤسسة النقد العربي السعودي، ومؤسسة نقد البحرين، وبنك نيجارا المركزي .ماليزيا، بالإضافة إلى البنك الإسلامي للتنمية، وصندوق النقد الدولي. ويهتم البحلس بإصــــار معايير الرقابة والإشراف، و تطوير آليات لإدارة المخاطر بالمصارف الإسلامية. ولعلَّ من المفيد -بعد عرض واقع العمل المصري في الإســلامي وتطـــوره- تقـــيمي التجربة المصرفية الإسلامية لا سيمًّا بعد مضي وقت ليس بالقصير على وجودها، المها، وبعد

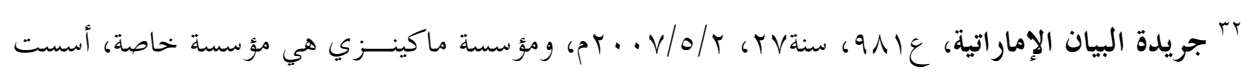

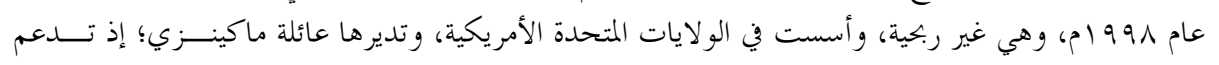

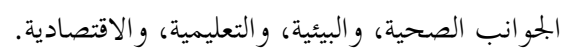

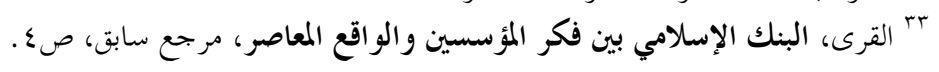




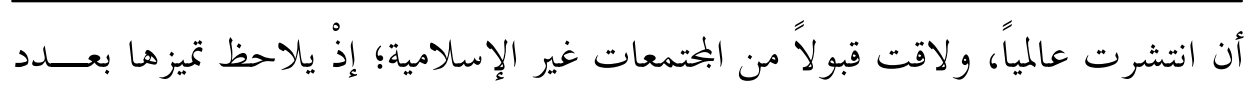
من نقاط القوة، و في المقابل تعالن من بعض نقاط الضعف. و تتمثل مـــواطن القـــوة في العمل المصروفي الإسالمي في:

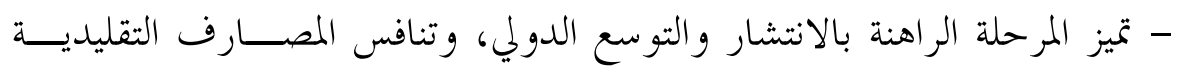

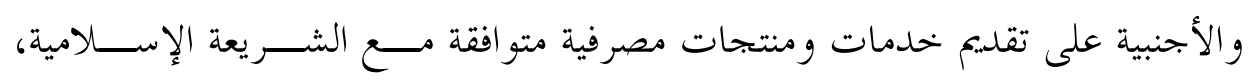

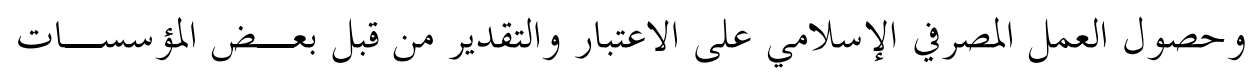
الدولية كالبنك الدولي: وصندوق النقد الدولي. عا

- الالتزام بالمبادئ العامة اليت تحكم عمليات التمويل في البنوك الإسالامية، و تتمثل هذه المبادئ هُ في: مبدأ الالتزام بالضو ابط الشرعية لا سيما حرمة التعامل بالربا؛ ومبدأ العمل بقاعدة الغنم بالغرم، أو الخراج بالضمان، عوض الفائدة الخرمة، و مبدأ ارتبـــاط

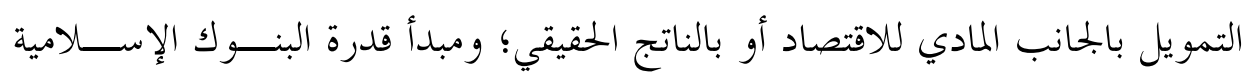

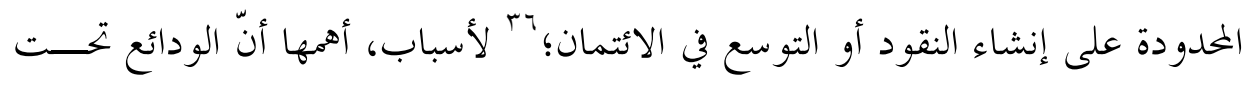
الطلب تعدّ المصدر الأساس لتوليد النقد، ووزها النسبي كبير في البنـــوك التقليديـــة؛ لاعتمادها على الإقراض، أما البنوك الإسالامية فإن حجمها ضئيل مقارنة بكجم ودائع

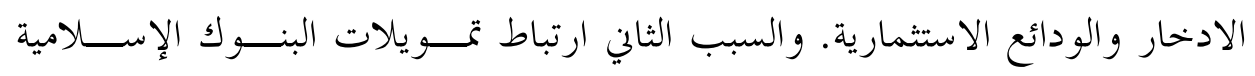
بعمليات اقتصادية حقيقية.

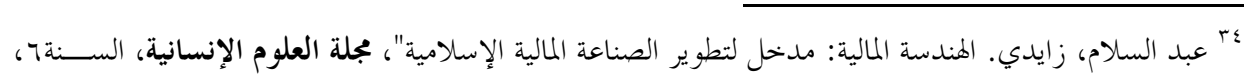
ن

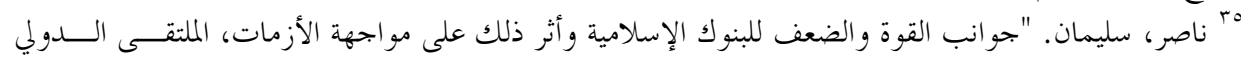

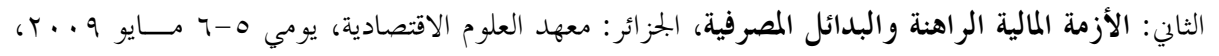

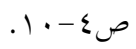

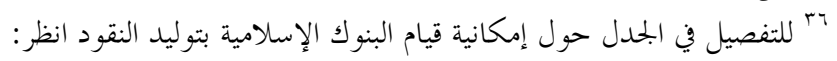

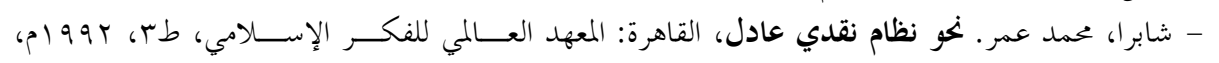
- يسري، عبد الرحمن. قضايا اقتصادية معاصرة في النقود والبنوك والتمويل، الإسكندرية: الدار الجحامعيــة،

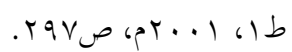
rV سليمان. جوانب القوة والضعف للبنوك الإسلامية وأثر ذلك على مواجهة الأزمات، مرجع سابق، ص. I- - 
- و جود الهيئات و المؤسسات الداعمة للعمل المصرفي الإسلامي. أما أهم جو انب الضعف في العمل المصرفي الإسلامي فتتمثل في: - إخفاق المصارف الإسلامية في بتحسيد مبدأ المشاركة بوصفه بديلاً للمعسـاملات

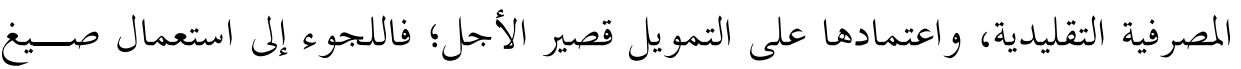

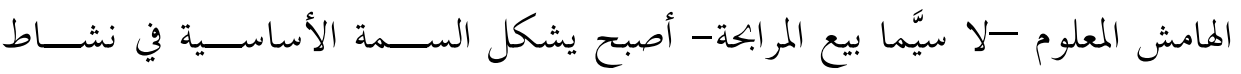

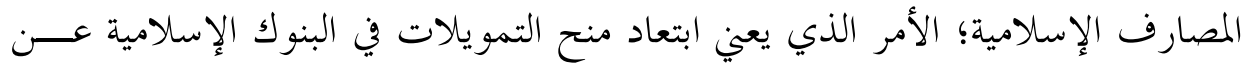

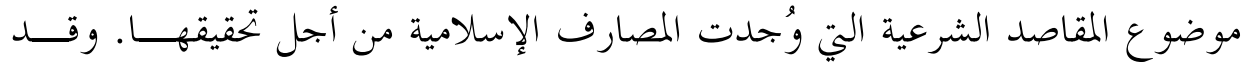

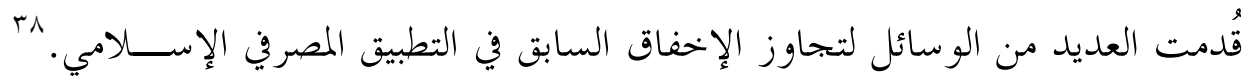
وأرى أن على السلطات الرقابية المشرفة على هذه البنوك في أي نظام مصرفي التـــدخل

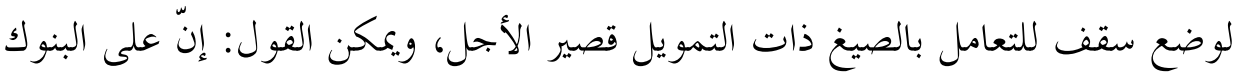

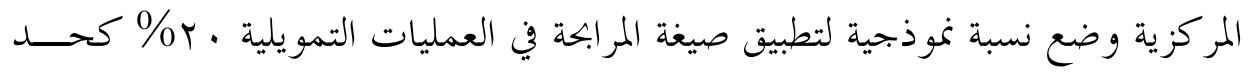
أقصى من بحمو ع استخداماها.

- صغر حجم البنوك الإسلامية: إن صغر حجم البنوك الإسلامية أدى إلى ضعف

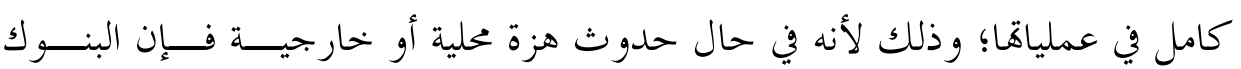

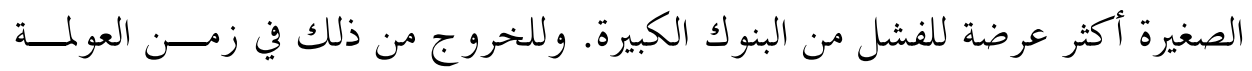

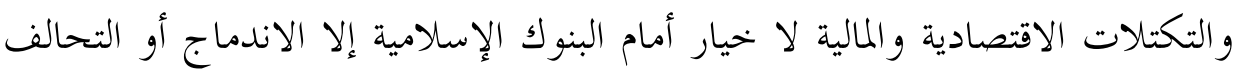
الاستر اتيجي لبقائها وضمان منافستها.

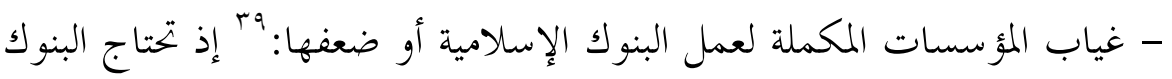

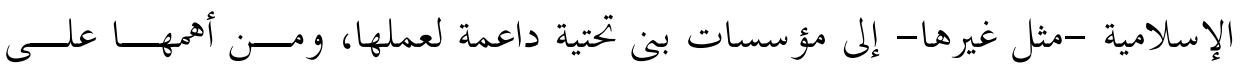

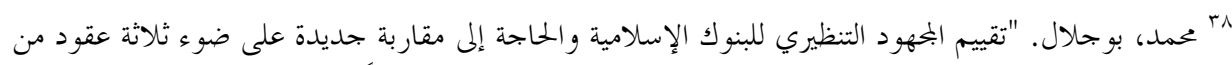

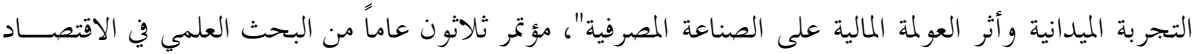

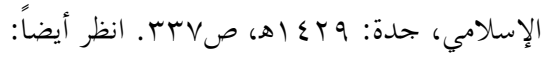

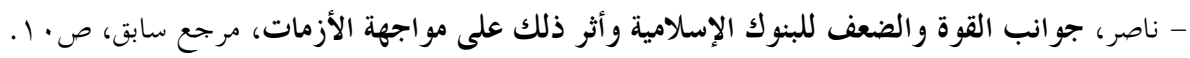

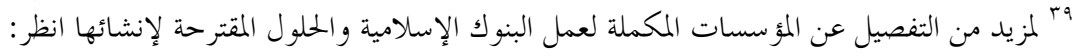

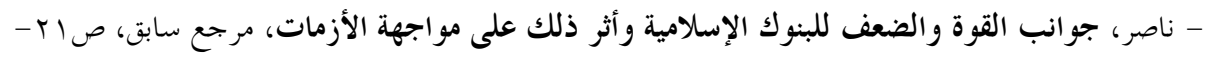




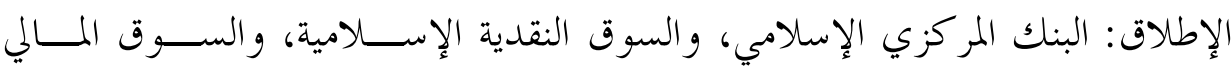

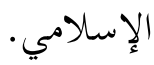

- الرقابة الشرعية واجهة خارجية: الرقابة الشرعية في غالبية المصارف الإسلامية

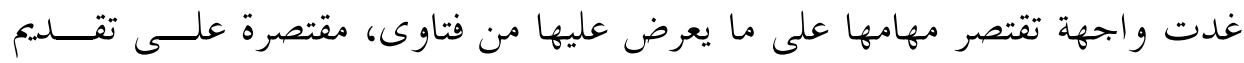

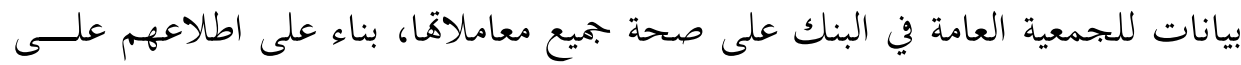

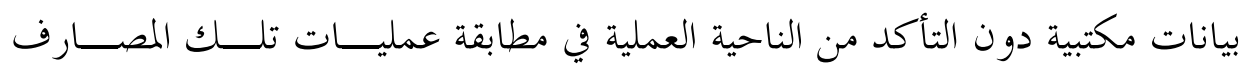

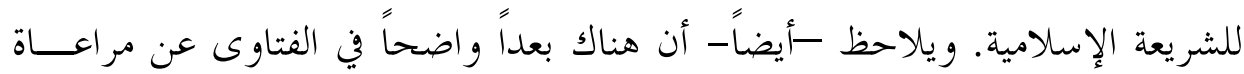

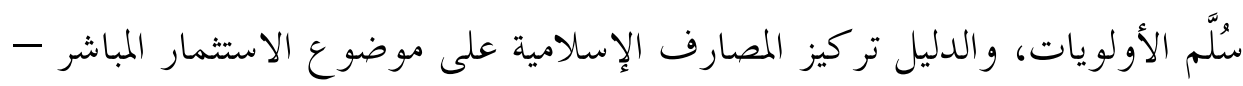

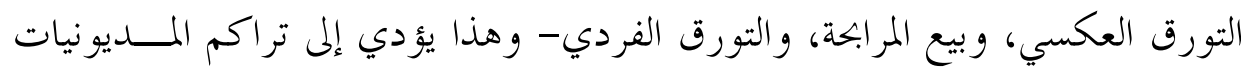

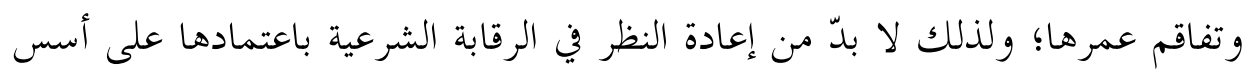
دقيقة تابعة لجهة خحار جية.

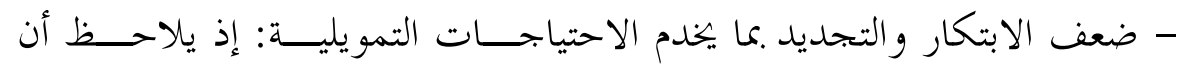

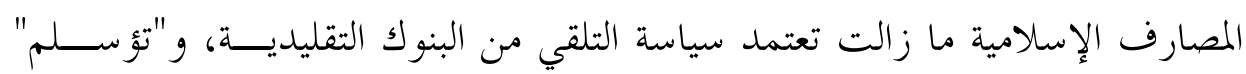

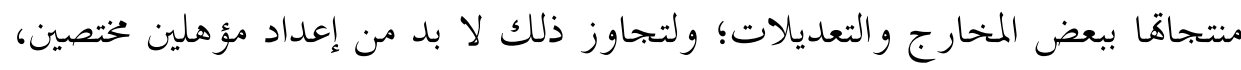

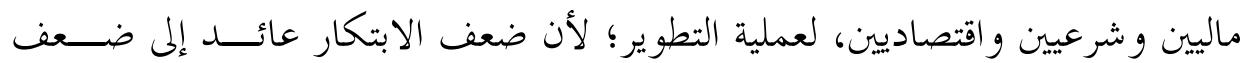

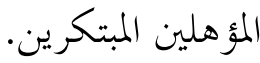

\section{القسم الثاني: حكمة العمل المصرفي الإسلامي}

لقد تطور العلم المصرفي الإسلامي تطوراً لافتاً فارضاً نفسه على الساحة المصرفية

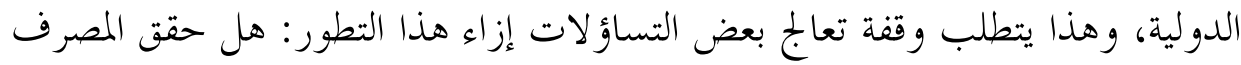

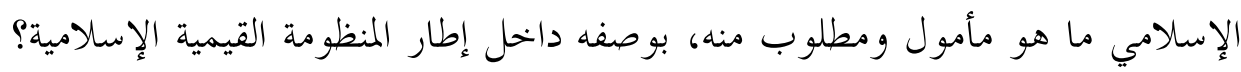

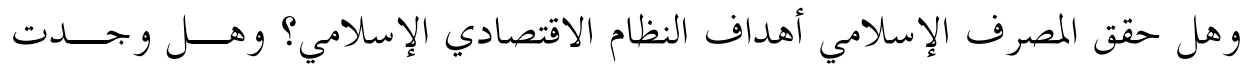

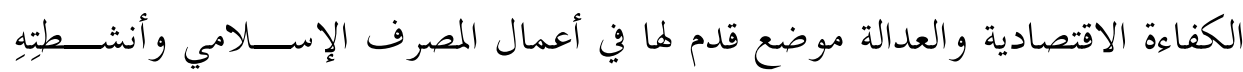




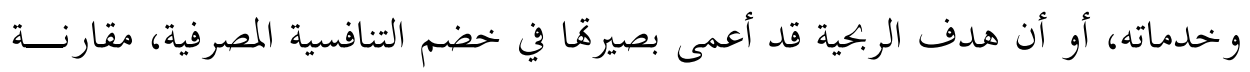

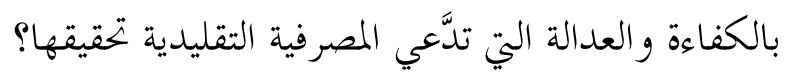

والوقفة عند هذه التساؤلات -تحقيقاً لهدف البحث في إبراز حكمة العمل المصرفي

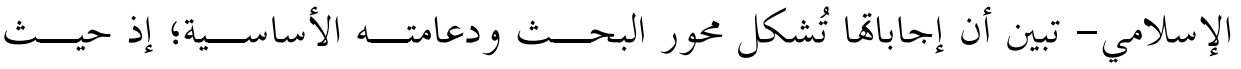

تستخلص حكمة العمل المصرفي من العمل المصرفي الإسلامي وتحقيق أهداف النظـــام

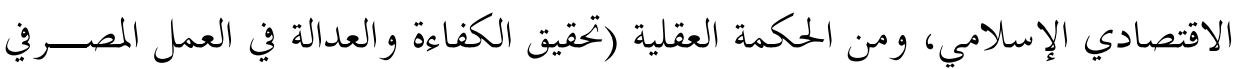

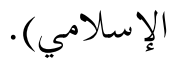

\section{أولاً: العمل المصرفي الإسلامي وتحقيق أهداف النظام الاقتصادي الإسلامي}

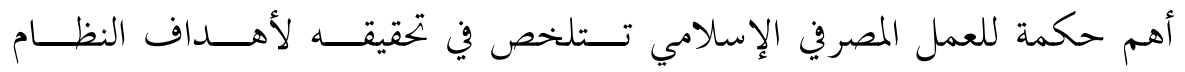

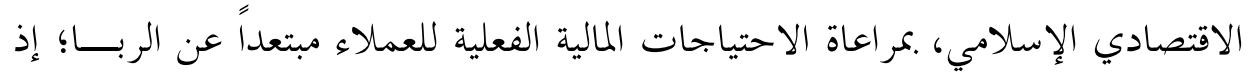

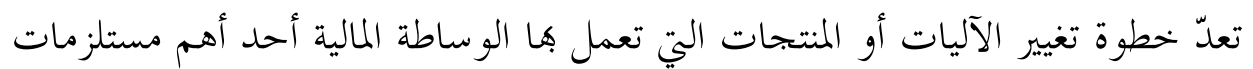

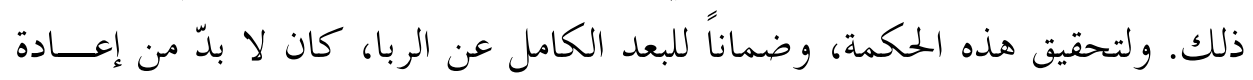

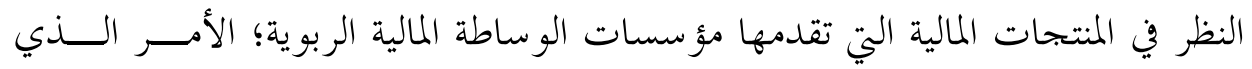

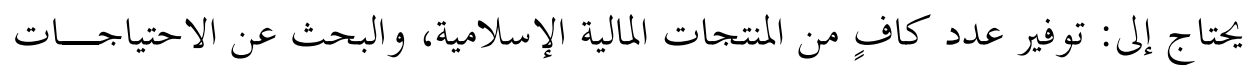
الفعلية للعملاء، و تصميم المنتجات المالية المناسبة لها.

\section{ا ـ كفاية المنتجات المالية الإسلامية: ‘؛}

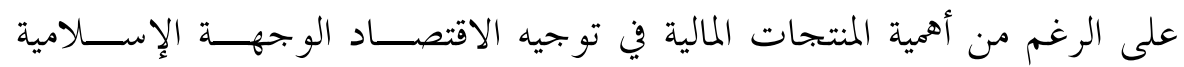

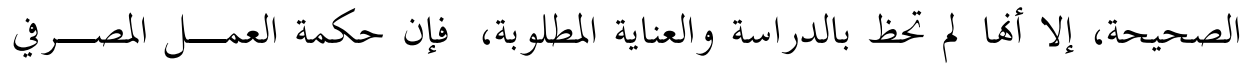
الإسلامي، تستلزم وجوب توفير عدد كاف من المنتجات المالية الإســالامية؛ لمراعـــاة

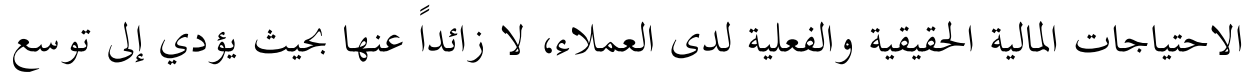

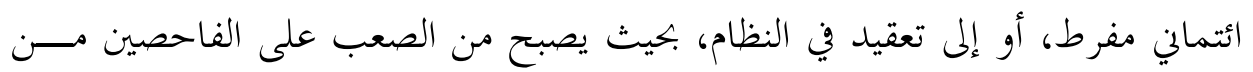


الخبراء تقويمه. ولتحقيق الاكتفاء من المنتجات المالية الإسلامية تقوم المؤسسات الماليـــة

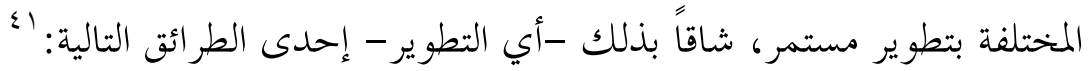

\section{أ. محاكاة المنتجات غير الإسلامية وتقليدها: ؟؛}

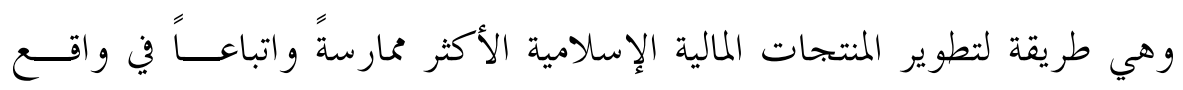

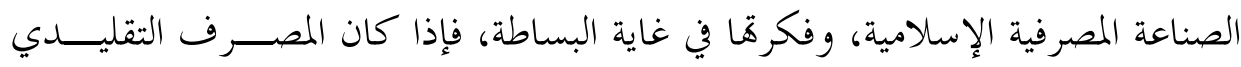

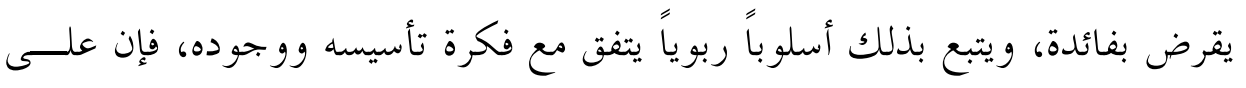

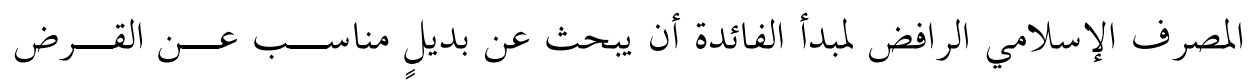

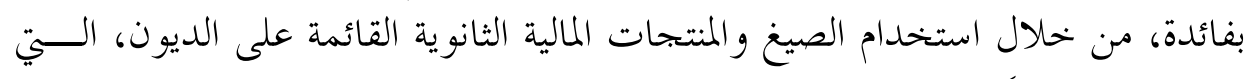
تعني أن يتم سلفاً تحديد النتيجة المطلوبة من المنتج الإسلامي -وهي النتيجة نفسها التي

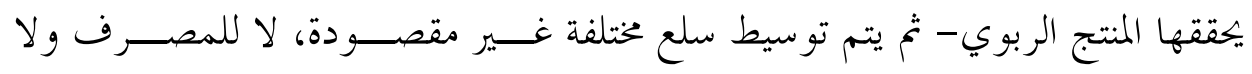
للعميل؛ للحصول في النهاية على النتيجة المطلوبة، وهي النقد الحاضر مقابل أكثر منه،

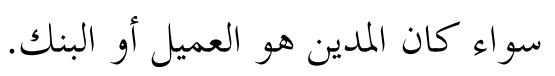

ويمكن تشبيه الفكرة السابقة للمحاكاة بالاستنساخ لمنتجات ماليــة إســلامية في رحم منتجات مالية تقليدية، كما في التورّق المنظم، وبيع المرابحة للآمر بالشراء بلجــــد حصول العميل على النقد.

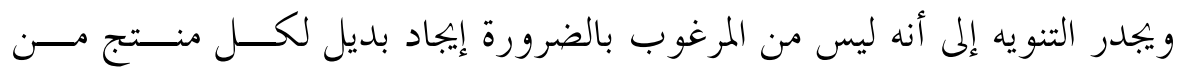
المنتجات الربوية التقليدية، وربما لا يمكن فعل ذلك في الواقع؛ فالنظام الإسلامي مع أنه

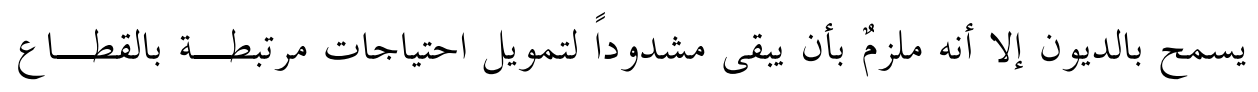
\& الحقيقي.

اء سويلم، سامي. المنتجات المالية الإسلامية بين الإبداع والتقليد، صحيفة الاقتصادية الإلكترونية، بr ســبتمبر http://www.aleqt.com/2006/09/23/article_57834.html

$$
\text { .r. T }
$$

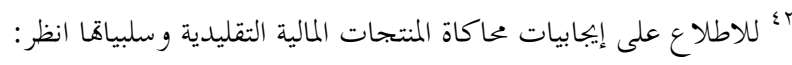

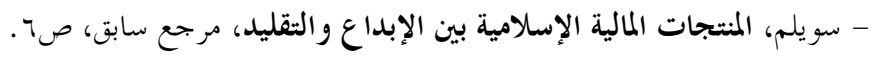

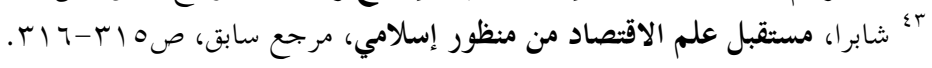


ب. البحث عن الاحتياجات الفعلية للعملاء، وتصميم المنتجات المالية المناسبة لها. هذا البحث هو مصدرٌ لإِبداع و الابتكار؛ إذ يتطلب دراسة مستمرة لاحتياجات العملاء، و يتطلب العمل على تطوير الأساليب التقنية والفنية اللازمة لها. وهذه الطريقة

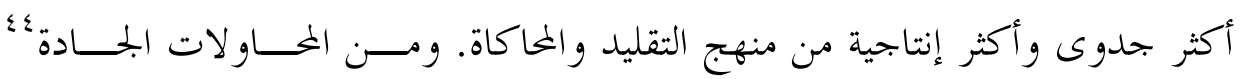
لتصميم منتجات مالية تتناسب واحتياجات العملاء، ما بحثثه ممثلو البنوك الإسلامية في

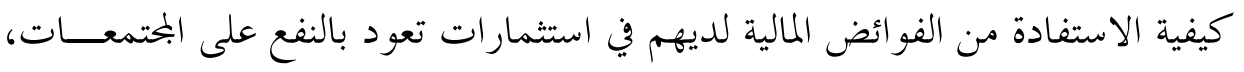
وذلك بإنشاء بنك دولي ضختم، يلعب دور صانع الســـوق، ويــــوفر الأدوات الماليـــة

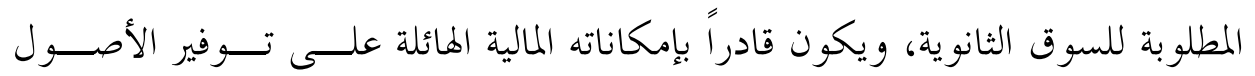
والاستثمارات، وتوظيف الأموال في هذه الأصول الحقيقية.

وأشار سامي سويلم إلى أن تطوير المنتجات المالية الإسلامية الأصلية الــيّ تلـبي الاحتياجات الفعلية لا يتم بين ليلة وضحاها، بل يتطلب الكثير من الجهجد و الإعــــاد.

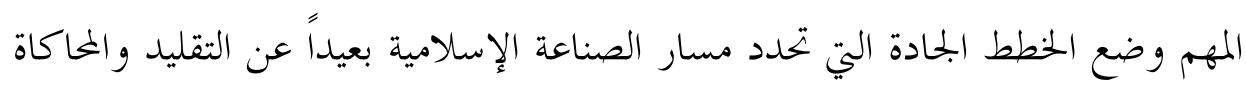

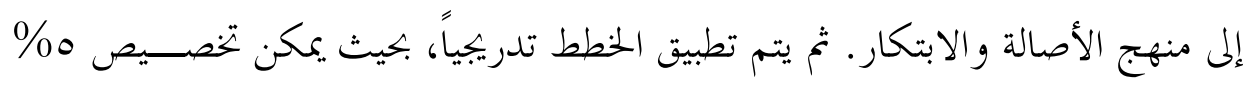
مثلاً من الميزانية السنوية للمؤسسات المالية لتطوير المنتجات المالية الجحديدة، على أن تتمَّم مراجعة النتائج وتقويم الأداء دورياً.

\section{Y ب ت بميط المنتجات المالية الإسلامية:}

التنميط هو توحيد مواصفات المنتجات المالية الإسلامية وأشـــكالها وأسســــا في جميع المؤسسات المالية الإسلامية من خلال إيباد نمط موحد. لقد قفز الفقه التمــــيلي

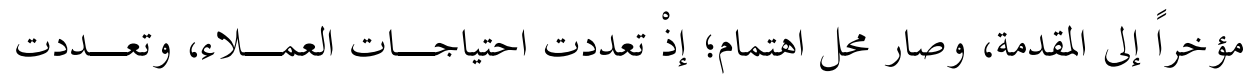

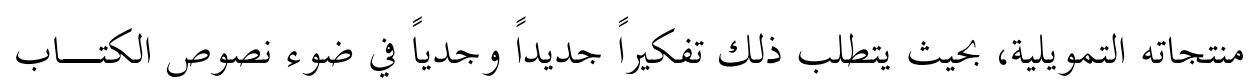

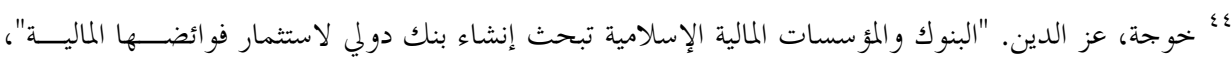

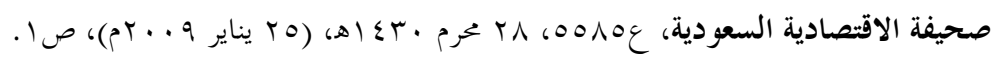

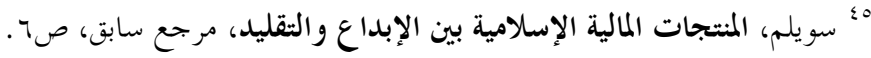


و السنة لهذه المنتجات التمويلية، و لعل أهم مشكلات التمويل الإسلامي أن منتجاتـــه المالية ليست منمّطة حتى الآن.

وفي ظل غياب المنتجات المنمّطة يضطر كل مصرف أن تكون له هيئسـة رقابـــة

شرعية، ولكل هيئة شرعية معاييرها لجواز المنتج المالي، حتى إن بعض المصارف لا تتقيد

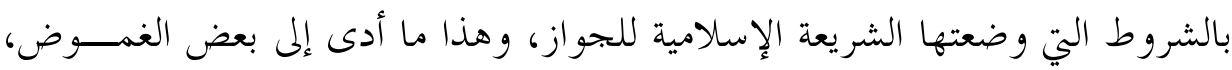

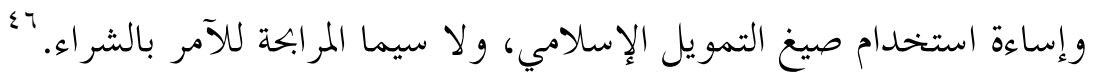
ويمكن للهيئات والبحالس المختصة بالمصرفية الإســلامية أن تســـاعد في تنمــيط

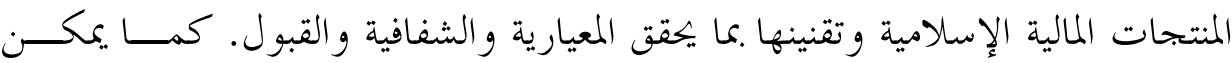

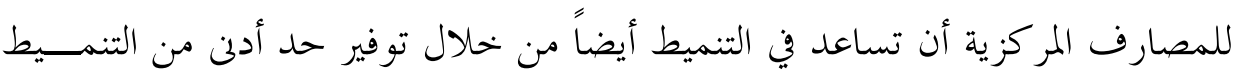

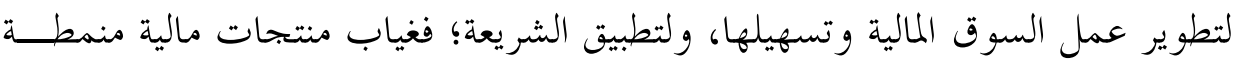
بصورة كافية يعد من أكبر العوائق للعمل المصري الإسالامي.

\section{ثانياً: الحكمة العقلية (تحقيق الكفاءة والعدالة في العمل المصرفي الإسلامي)}

تتجلى الحكمة العقلية -بمعنى الباعث والغاية العقلية- للعمل المصرفي الإســامي بتحقيق أهداف الإسلام في العدالة والكفاءة. V؛ وهي أهدافه ما انفكت عن أي تشريع سماوي، فالعدل هو الأساس، و العدالة مطلبُ ضروري. و التشريعات الإسلامية الخاصة بالمعاملات تبين لنا العدالة بأجلى صورها كما في تشــريعات المــيراث، والزكـــاة، و الصدقات، وتحريم بعض البيوع لعدم تحقق العدالة، وتحريم الربا؛ لما يؤديهِ ذلك مـــن نخرٍ في جسد العدالة، وغيرها.

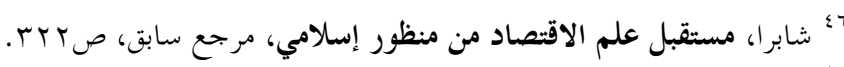

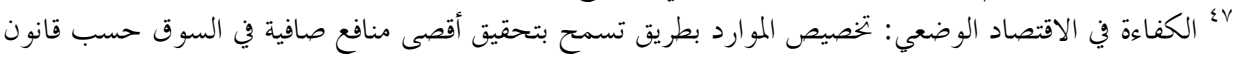

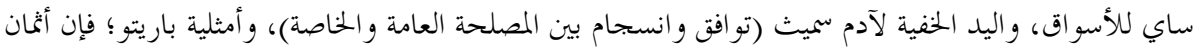
السلع في السوق هي التي تحدد الكفاءة في السوق، ومن ضمنها لإنها سعر الفائدة. 


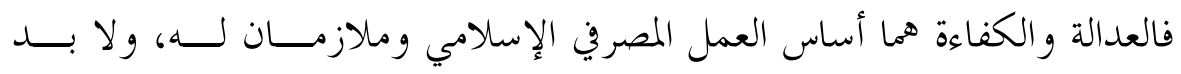
للمصارف الإسلامية عند عملها تحت مظلة المنظومة القيمية الإسامية أن تراعـيَّ - في صلب عملها- متطلبات الحكمة العقلية بتحقيق العدالة والكفاءة.

\section{ا ـ تحقيق أهداف الإسلام من العدالة والمساواة:}

إقامة العدالة من أهم مستلزمات العمل المصرفي الإسلامي، وإن الحلكمة العقليــة الأولى والأهم من وراء إلغاء الربا و الفائدة هي إقامة العدل؛ ففي عهد النبي -صلى الله

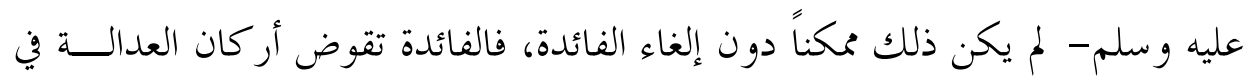
البحتمع المسلم، وبيان ذلك من خلال:

أ. الفائدة والاستغلال: الإقراض بالفائدة يؤدي إلى استغلال؛ استغلال الأفــــاد

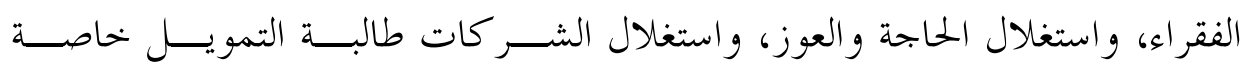
المشروعات الصغيرة، و استغلال المؤسسات. أي بمعنى استغلال وحدات العجز طالبـــة

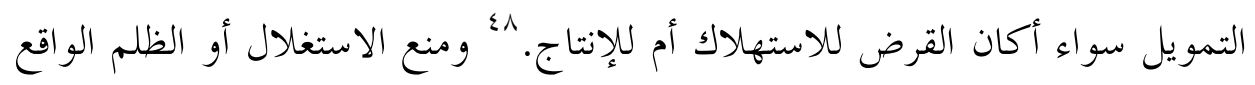

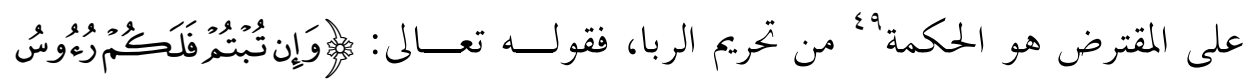

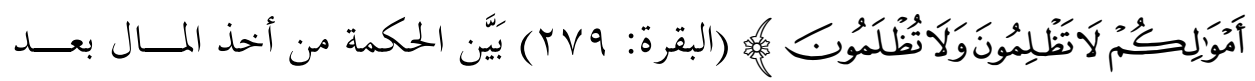
التوبة، وهو رفع الظلم على المقرض و المقترض؛ فمن الظلم أن يطلب الدائن زيادة على لى رأس المال الذي أخذه. و الربا ظلم؛ لأنه لا يبالي بآلام المختاجين، ويسعى إلى اســتغلال

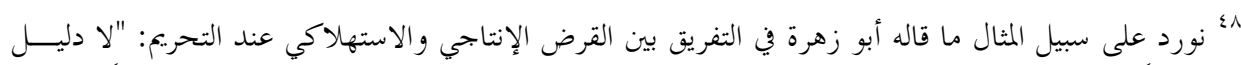

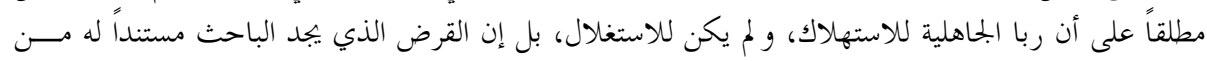

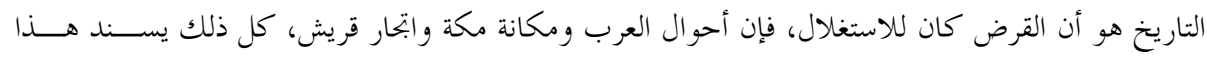

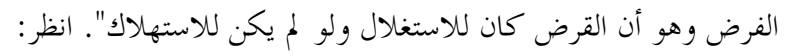

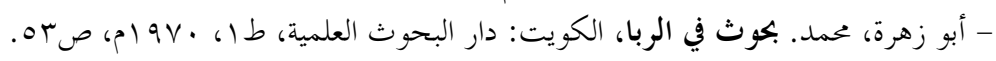

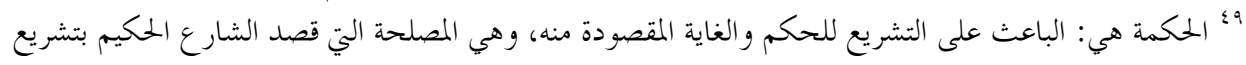

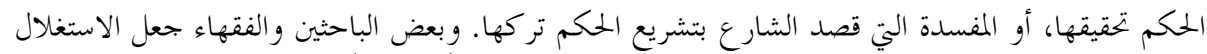

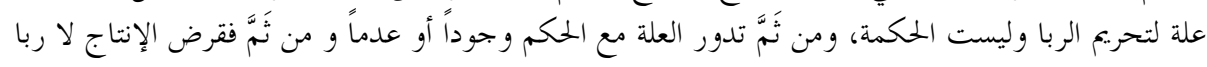

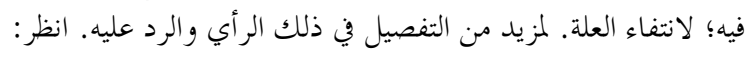

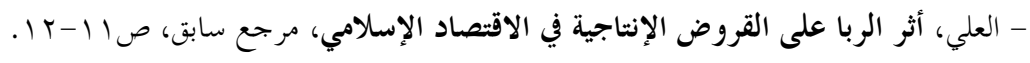


حاجاهم، ويصبح المرابي أنانياً لا يهمه سوى تكديس المال على حساب الآخرين. وفيه

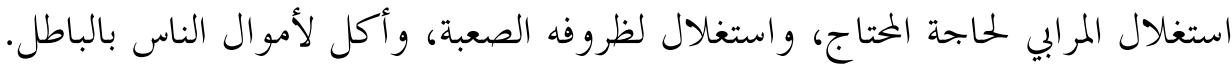

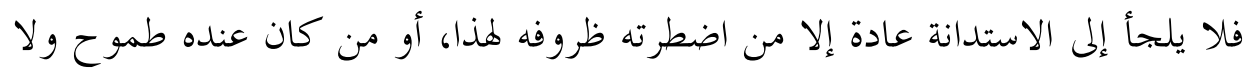
يجد ما يجققه إلا عن طريق الاستدانة.

وقد أدرك الكثير من العقلاء ذلك، فأفلاطون وأرسطو توماس الإكويني صــرحوا

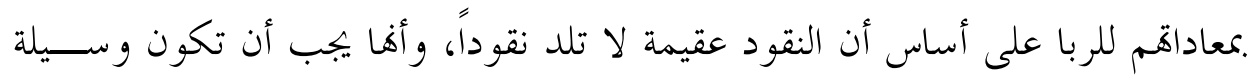

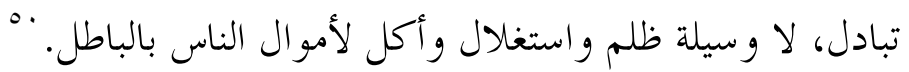
مما سبق يلاحظ أن من مستلزمات العدالة في العمل المصرفي الإسلامي رفع الظلم

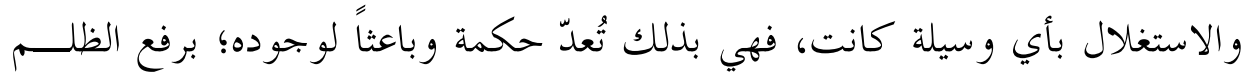

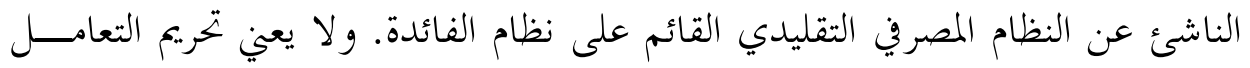

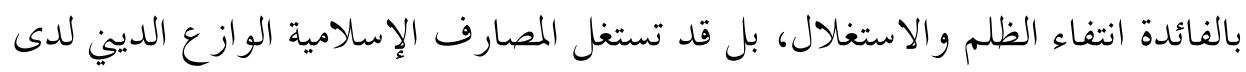

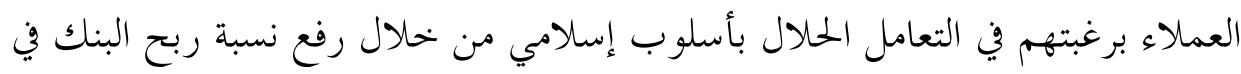

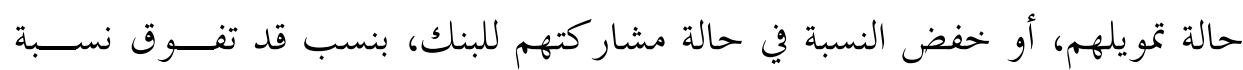

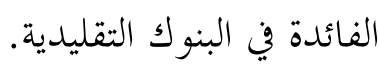

ب. المخاطرة في تبرير الفائدة: العدالة التي تنشدها الشريعة الإسلامية مــن وراء

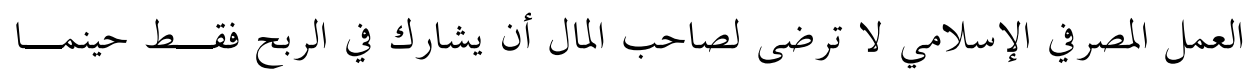

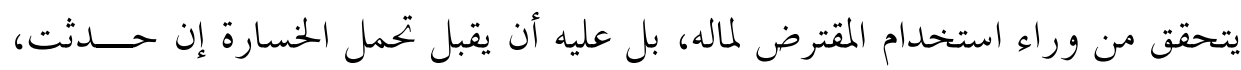

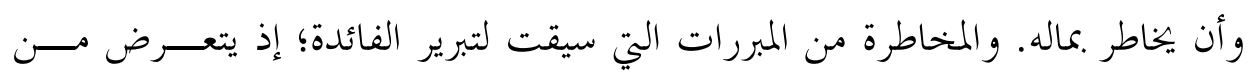

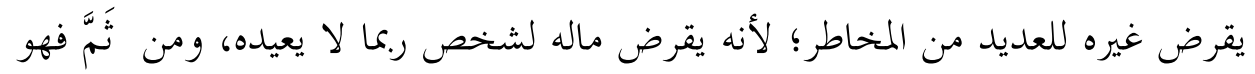
يخاطر بماله مستحقاً بذلك الفائدة، فيرد عليه:

- هذه المخاطر لا تتعلق بالنشاط الاقتصادي، ولا بما يترتب على توظيف القرض من نتائج؛ لأنّ أصل القرض مضمون في ذمة المقترض، وهي بذلك مخاطر تتعلق بالذمم

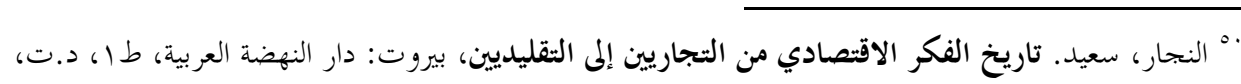




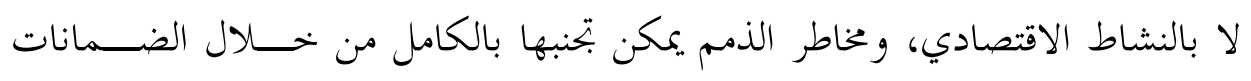

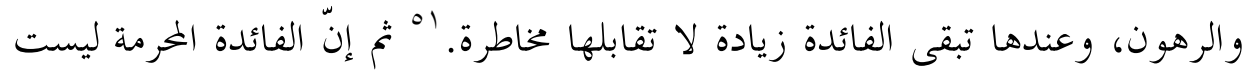
هي ما يضمن أصل القرض، بل أصل القرض مضمون في ذمة المقترض وموثِّق بالرهون و الضمانات.

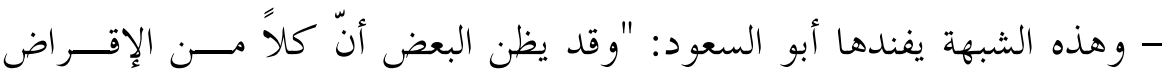
والإيداع يتضمن نوعاً من المخاطرة، إذ قد يفلس المقترض أو المودَع لديه (المصرف).

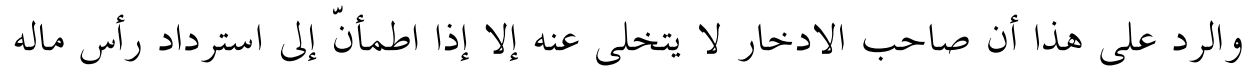

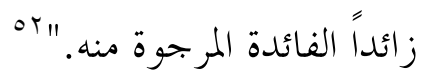

- إنّ القرض لا يمكن تبرير الربا فيه بالمخحاطرة، ولكنْ للمقترض ثوابُ عنــــــ الله

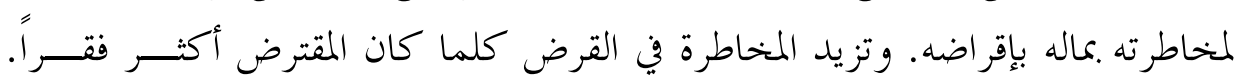

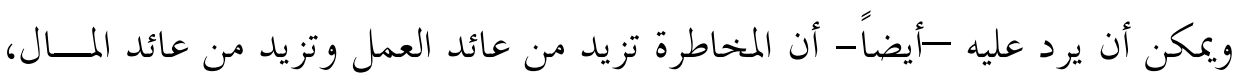

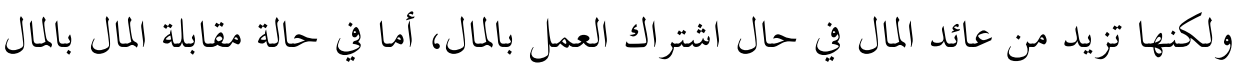

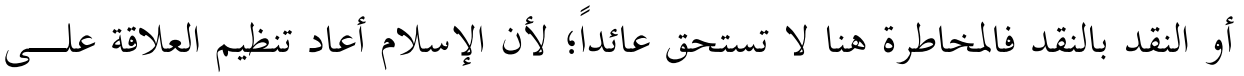

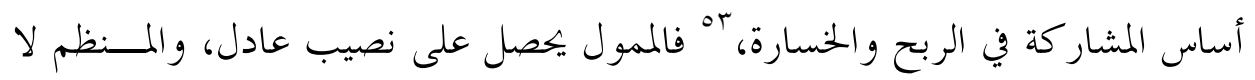

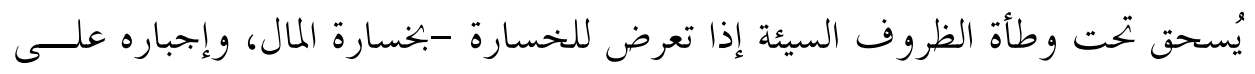

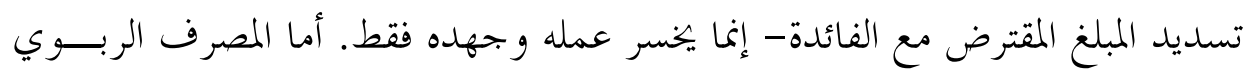
فيقدم المال إلى وحدات العجز مقابل تعهد برد مبلغ القرض مع فائدة محددة هي نسبة

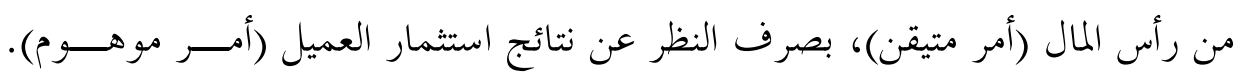

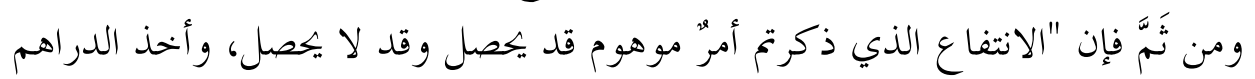

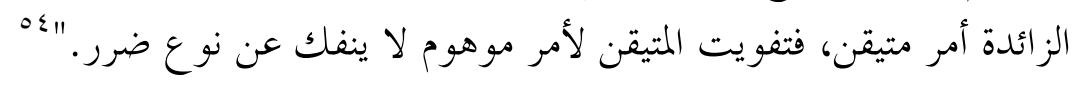

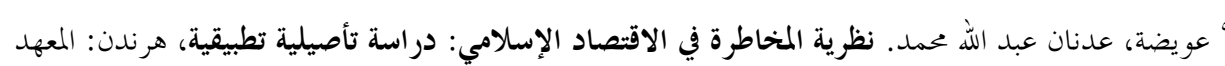

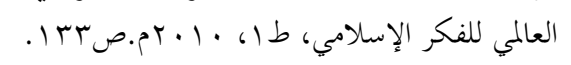

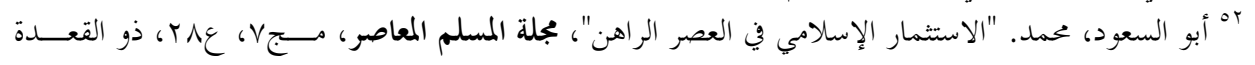

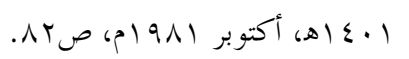

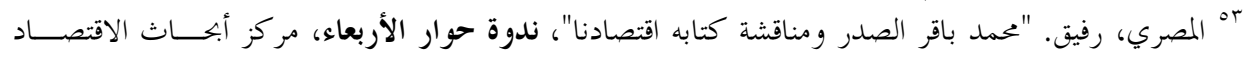

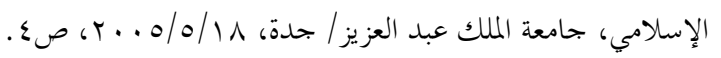

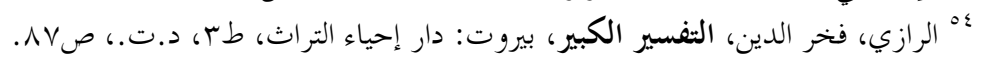




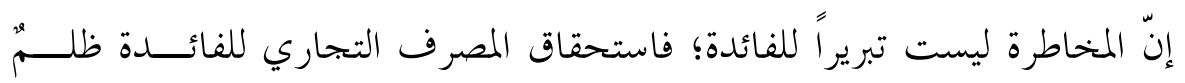

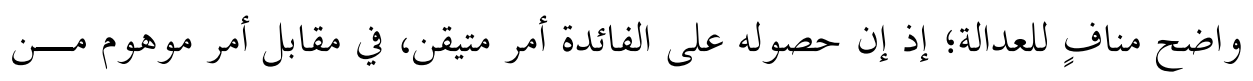

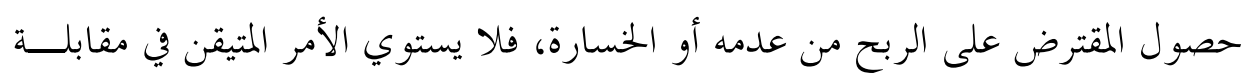

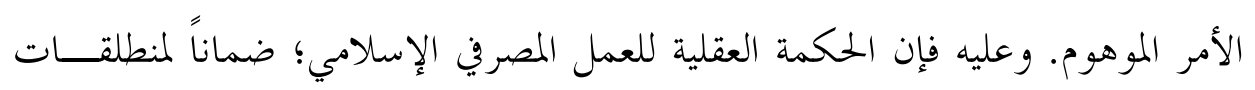

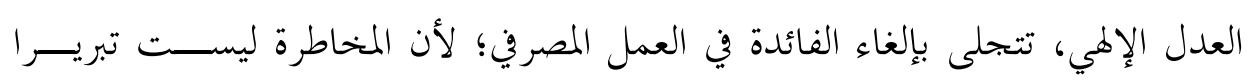

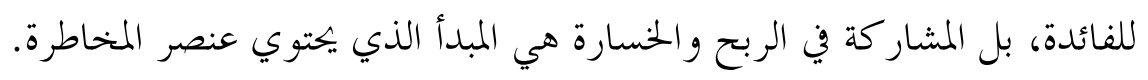

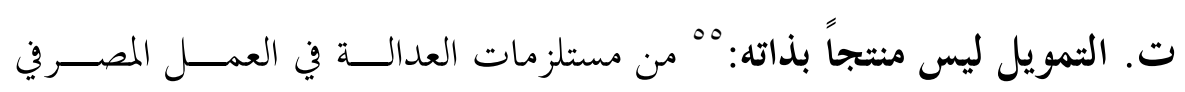

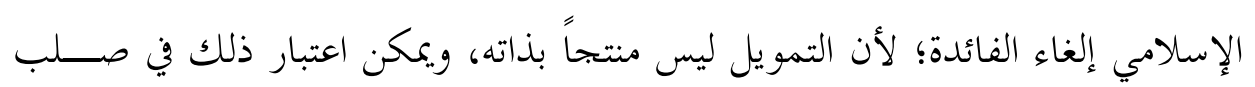

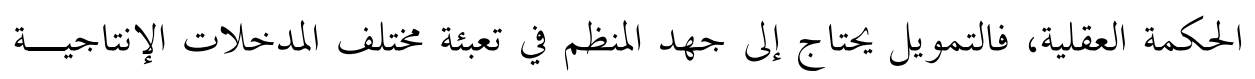

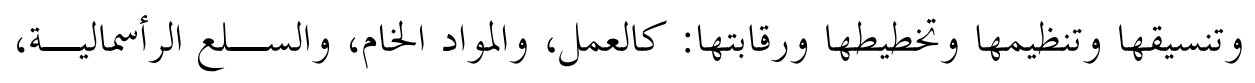

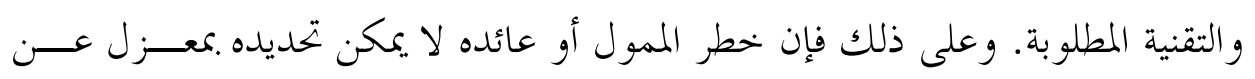

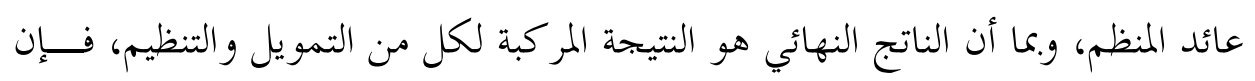
العدالة تتطلب اشتر اكهما معاً في الناتج بطريق عادلة.

ث. عدالة توزيع الدخل و الثروة: يؤدي النظام المصرفي التقليدي مهمة ســلبية في

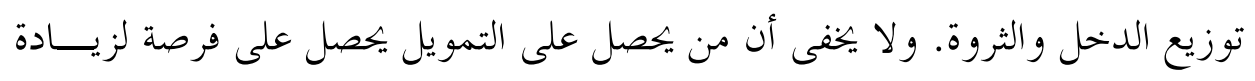

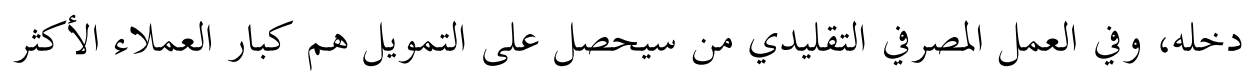

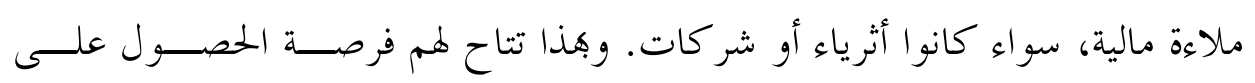

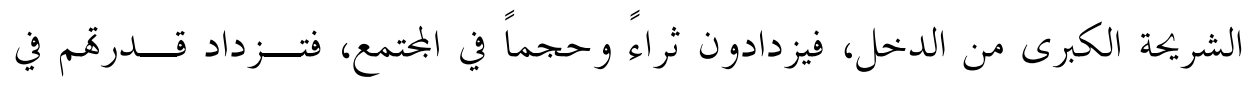
الخصول على التمويل والدخل.

ونظام الإقراض بالفائدة التقليدي لا يتيح -بناءً على قاعدة الملاءة المالية- لصغار

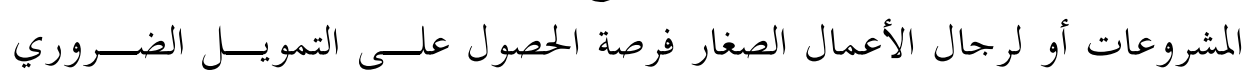

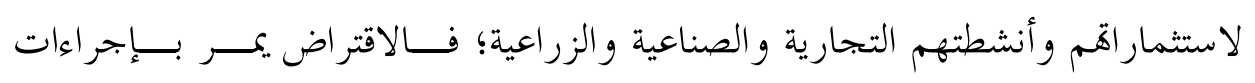

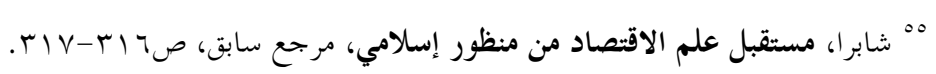


و تعقيدات معينة، و لا بد أن يخضع طالب التمويل لفحوصات دقيقة؛ للتأكد من قدرته

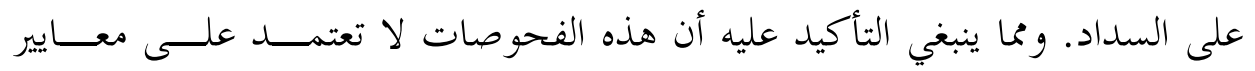

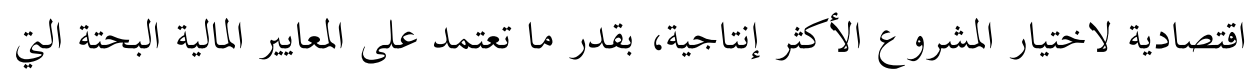

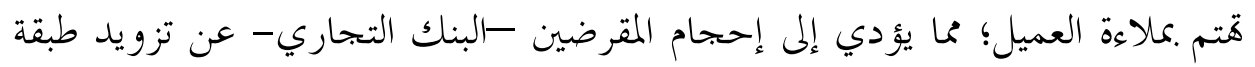

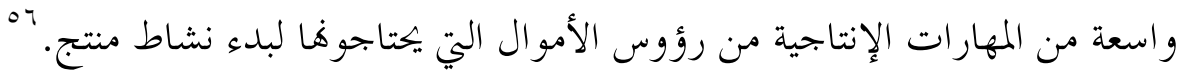

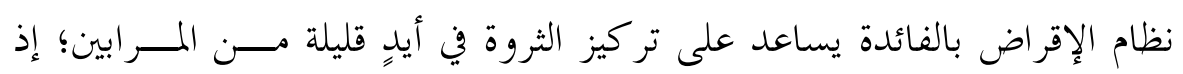

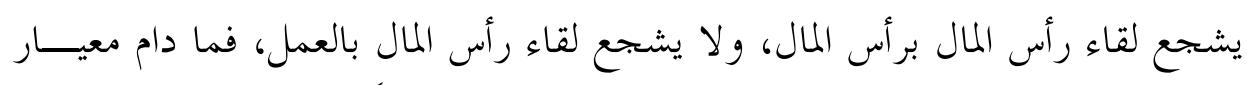

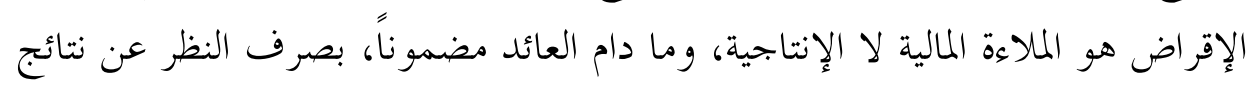

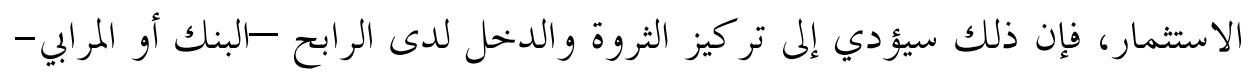

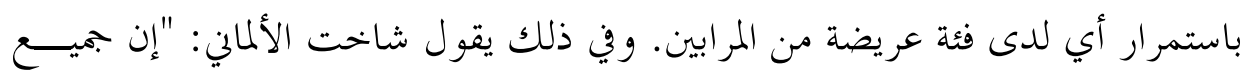

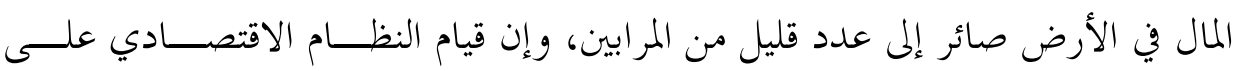

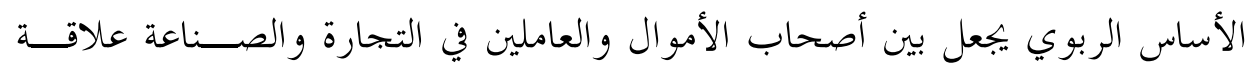

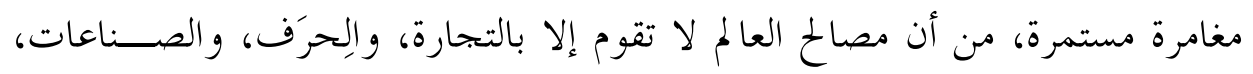

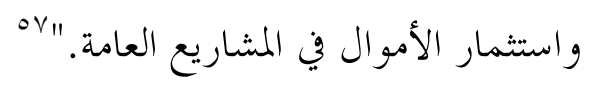

ويقوم نظام الفائدة -أيضاً - كمهمة سلبية في توزيع الدخل بين الكسالى والخاملين

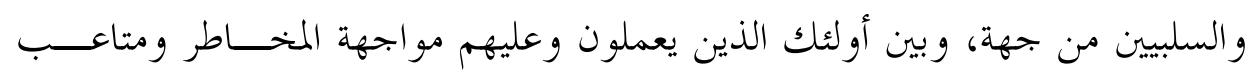

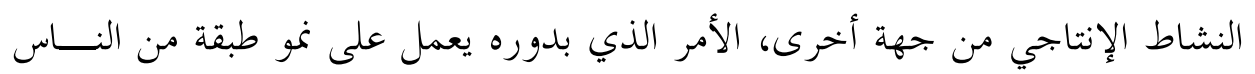

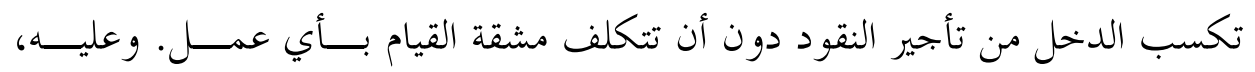
وحسب الآلية السابقة، فإن توزيع دخل الأعمال الإنتاجية في العمل المصرفي التقليدي

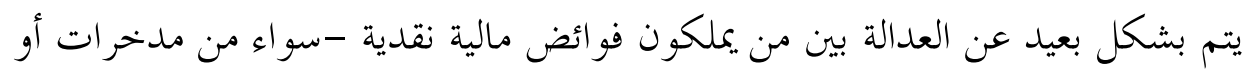

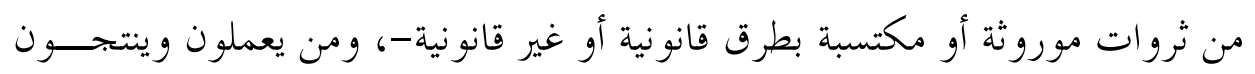

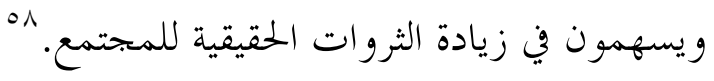

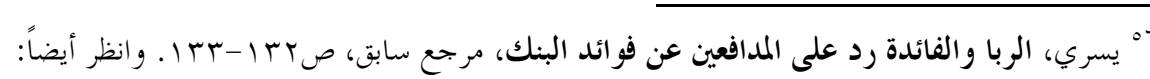

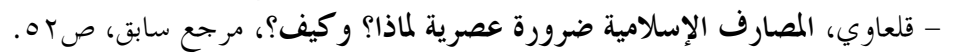

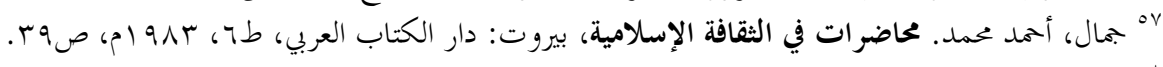

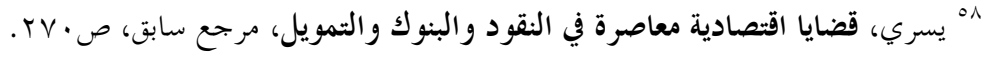




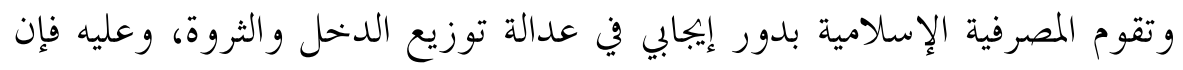

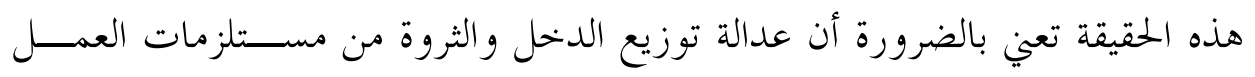

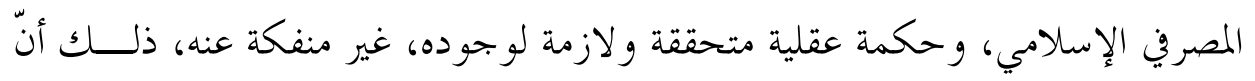

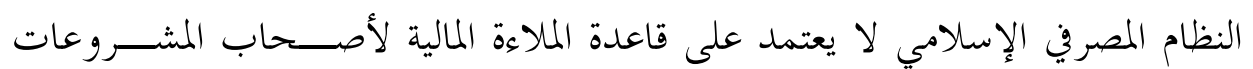

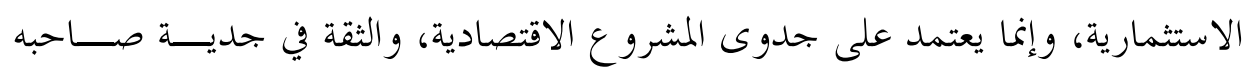

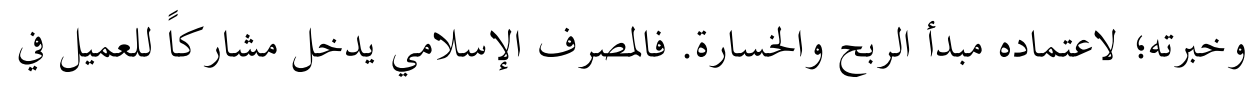

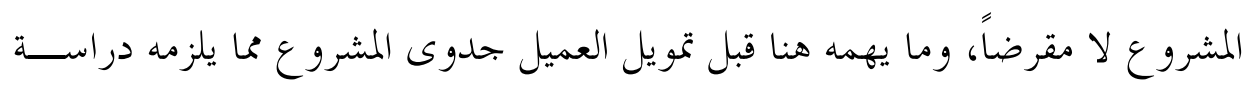

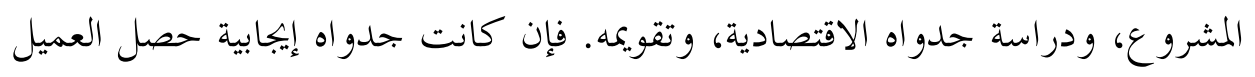

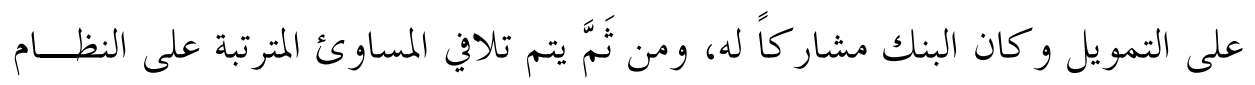

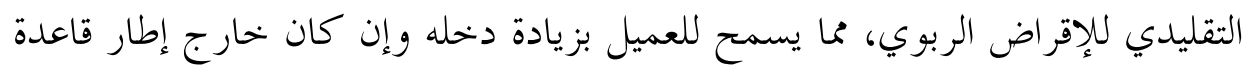

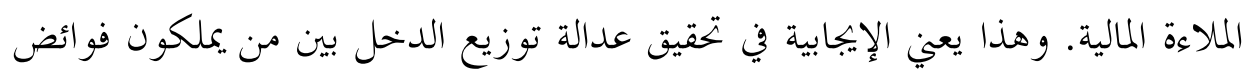
مالية نقدية قابلة للاستثمار وبين من يستثمروها.

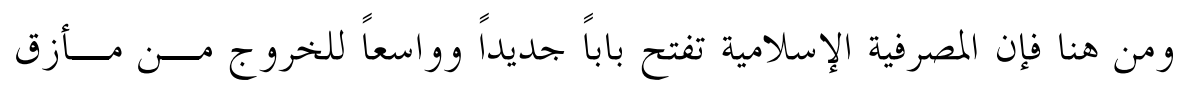

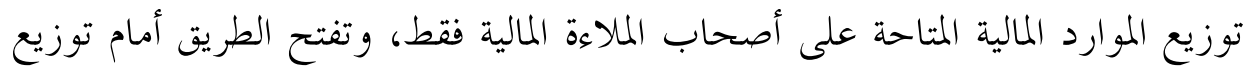

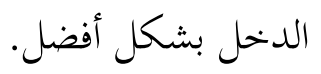

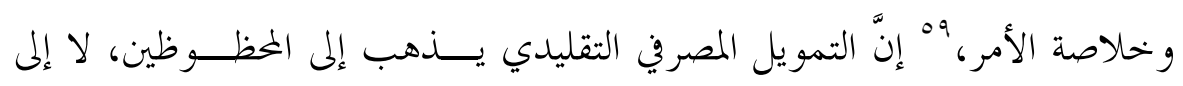

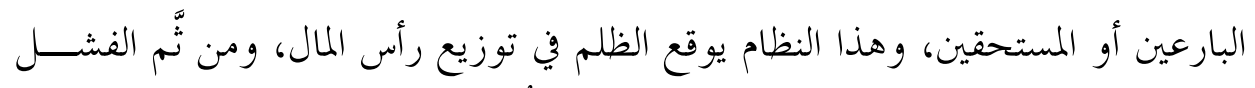

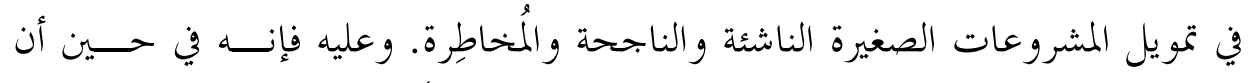

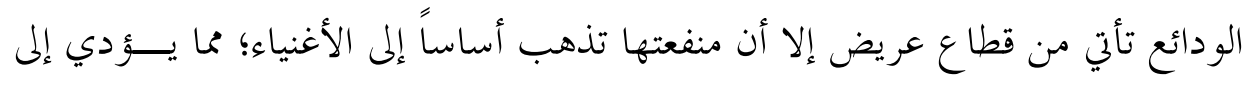

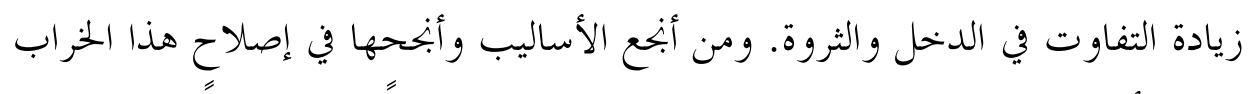

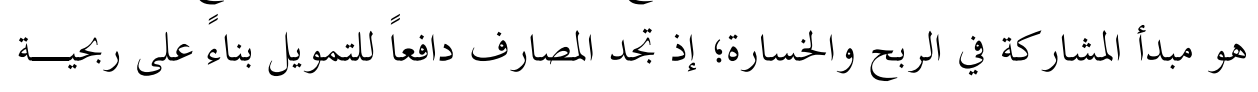

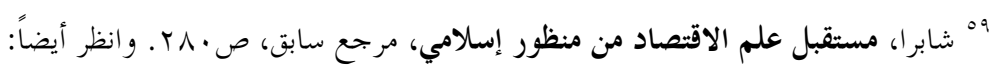

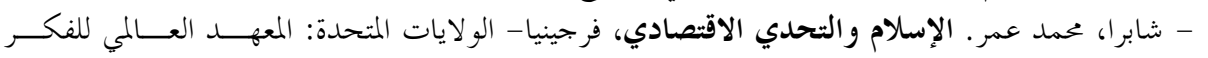

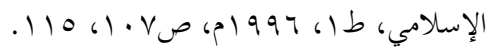


المشروع بالإضافة لما تعطيه من اهتمام للضمانات، وهذا تتمكن المنشآت الصغيرة من التنافس و الحصول على نصيب من الدخل.

\section{Y. الكفاءة في العمل المصرفي الإسلامي:}

الكفاءة الاقتصادية مصطلح اقتصادي وضعي، يعني: تخصيص الموارد الاقتصــادية بطريق تسمح بتحقيق منافع صافية في السوق. ولعلماء الاقتصاد الوضعي آراء متعددة في آلية تحقيق الكفاءة الاقتصادية في المجتمع، من خلال مبدأ اليد الخفية، وقانون ســاي

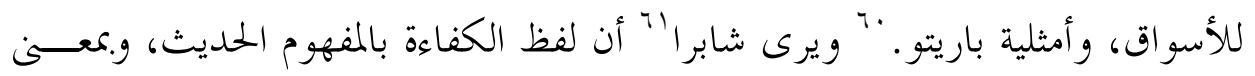

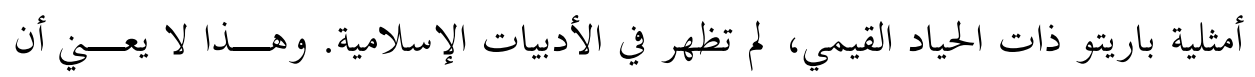

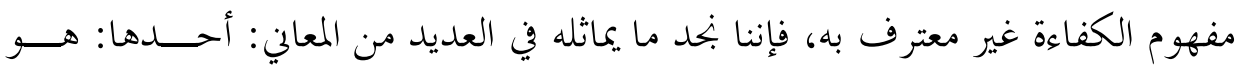

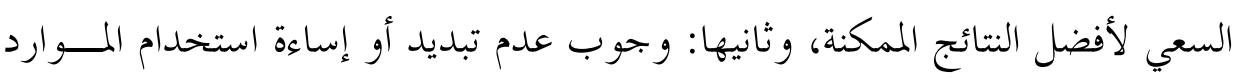
المختلفة. ففي حين أن استخدام الموارد المالية في علم الاقتصاد الوضعي يتحدد حسب أمثلية باريتو فإنه يتحدد في الاقتصاد الإسلامي حسب المقاصد الشرعية.

وما يهمنا في هذا المقام من البحث، بعد العرض الموجز لمفهوم الكفاءة، توضــيح

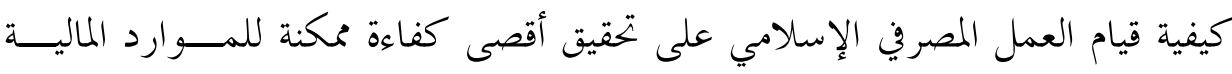

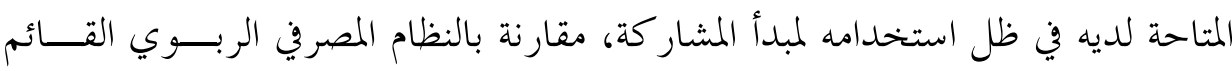

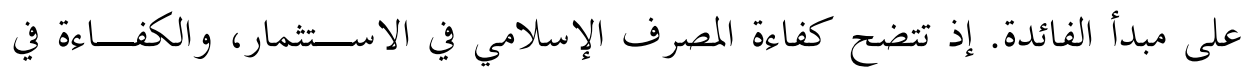

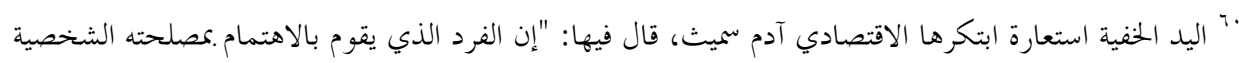

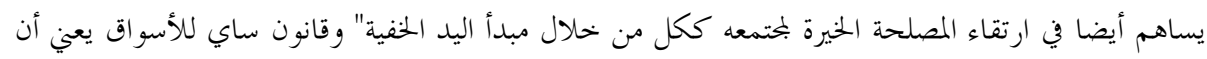

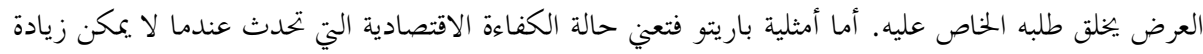

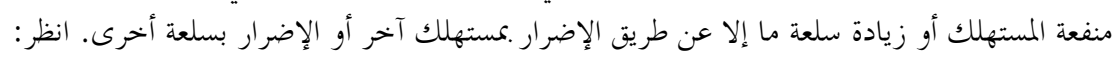
- Smith, Adam,(1970), The wealth of the nation, New York: The Modern Library, 1937, p423.

- Pareto, Vilferdo. Manual of political economy, Translated by Anns. Schwier. Edition by S. Schwier on Alfred. New York: A.M Kelly. P.P182

$$
\text { 1ل شابرا، مستقبل علم الاقتصاد من منظور إسلامي، مرجع سابق، ص | } 1 \text { | - | | } 1 \text { | }
$$


تخصيص الموارد المالية، والكفاءة في تحقيق الاستقرار الاقتصادي، والكفاءة في التنميــة

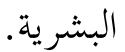

أ. الكفاءة في الاستثمار: هل العمل المصرفي الإسلامي أكثر قدرة و كفاءة علــى

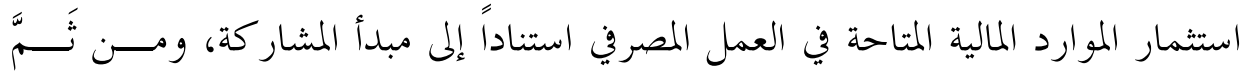

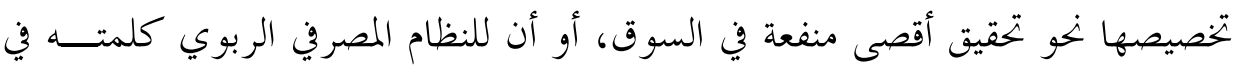
هذا المقام؟

تتضح معالم إجابة التساؤل السابق من خلال بيان دور سعر الفائـــدة في تحقيــق

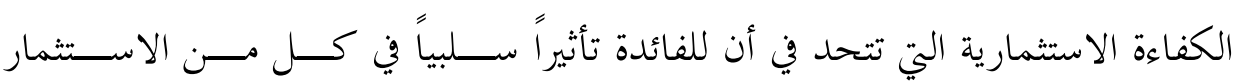
و الادِّحار، فقد أوضح كل من: Wicksell و keynes بَ أن الفائدة عبء وقيد على الاستثمار، فالمنظم يقارن بين كلفة التمويل (سعر الفائدة) والكفاءة الحدية للاســتثمار

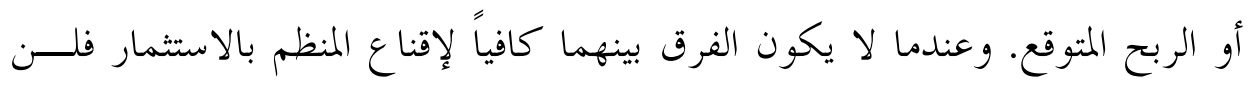

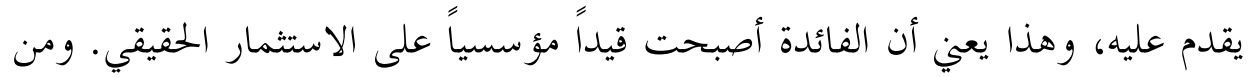

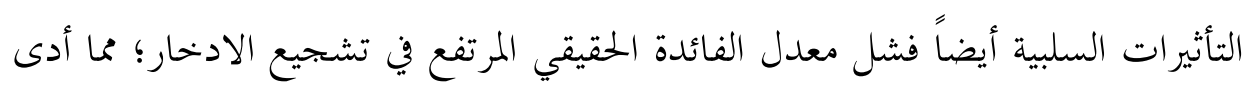
إلى الخفاض معدلات الزيادة في الاستثمار و النمو الاقتصادي.

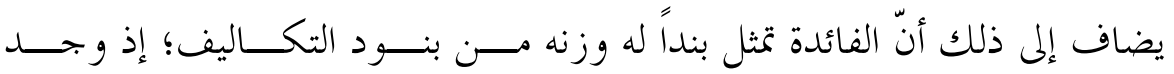
rr Leibling

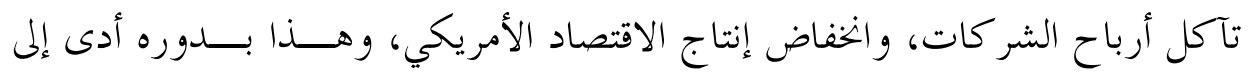
انخفاض التكوين الرأسمالي.

وتعد الفائدة قيداً على الاستثمار؛ نظراً للعلاقة العكسية بين سعر الفائدة وحجـــم

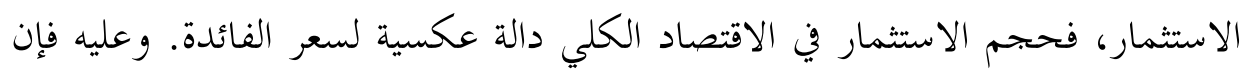

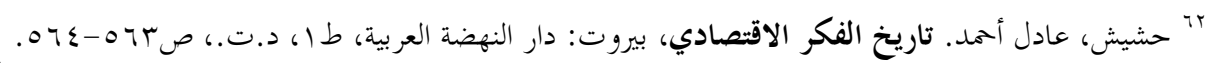
${ }^{63}$ Leibling, H.U.S. "Corporate Profitability and Capital Formation: Are Rates of return sufficient?" New York: Program on Policy Studies 1980. P70-78 


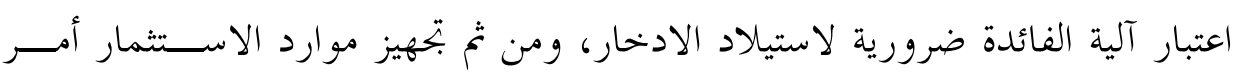

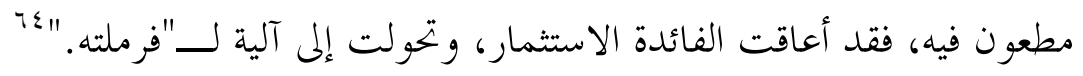

وقد أشار أحد تقارير البنك الدولي ْج إلى أن إدارة أسعار الفائدة مع السياســات

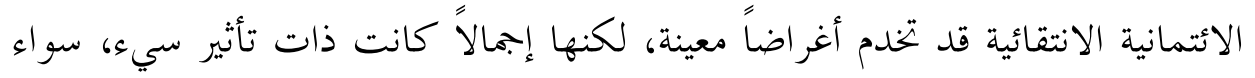

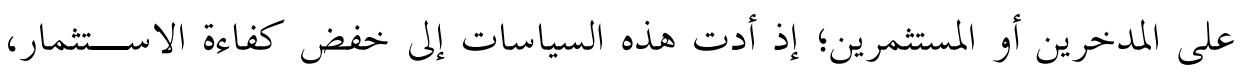
وإلى إساءة استخدام الموارد المالية.

ولإجحابة عن التساؤل حول إمكانية نظام المشاركة في تحقيق الكفاءة الاستثمارية للموارد المالية، يمكن القول: إن مبدأ المشاركة الذي تعمل به المصرفية الإسلامية يعـيني

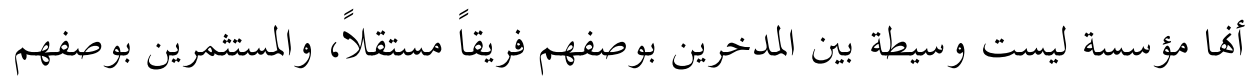

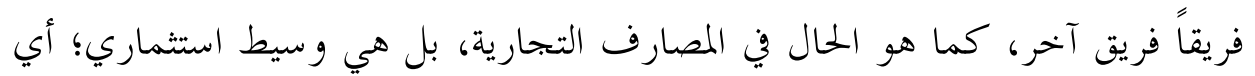

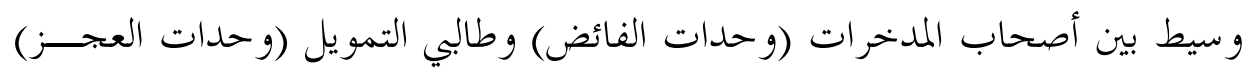

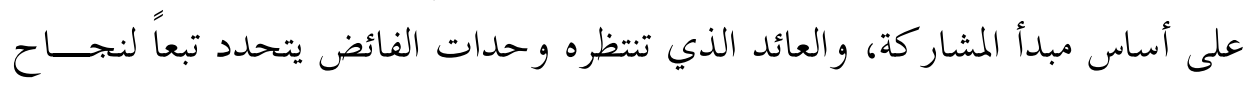

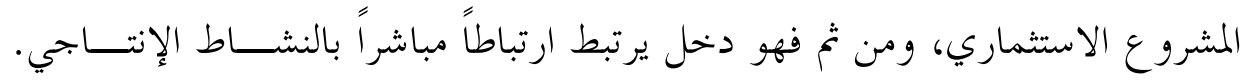

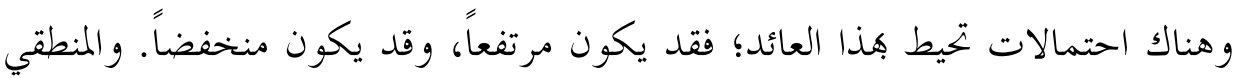

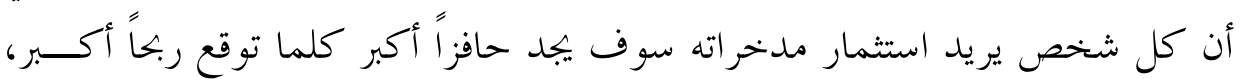

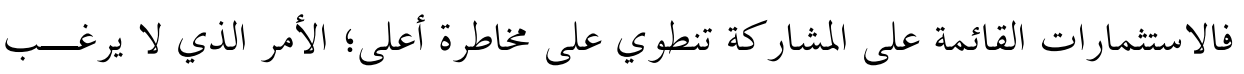

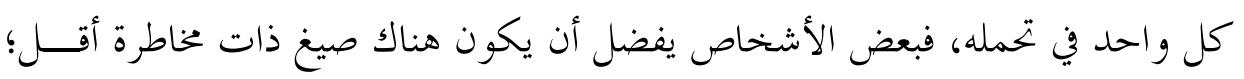

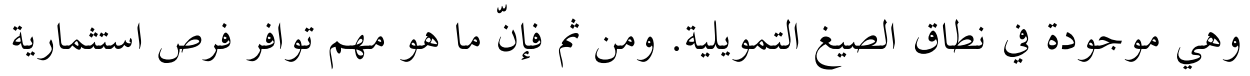

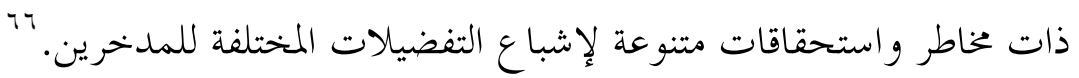

وهذا الأمر لا يتوفر في إطار نظام الفائدة؛ إذ إنَّ هناك قيوداً عديدة على ارتفــــاع

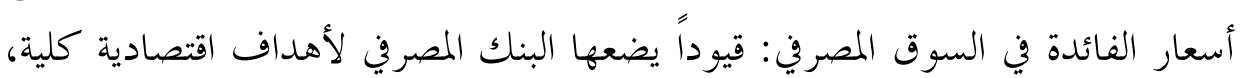

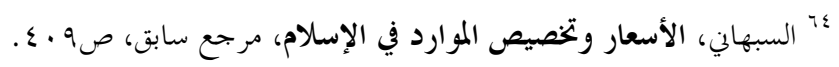

${ }^{65}$ World Development Report, World Bank, Staff Report no: 6710, April 1987, p715-716. "M شابرا، مستقبل علم الاقتصاد من منظور إسلامي، مرجع سابق، صع rV. 


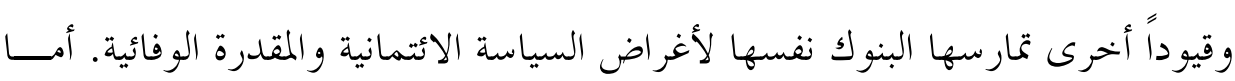

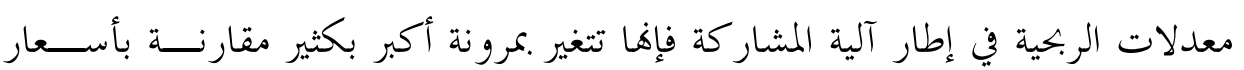

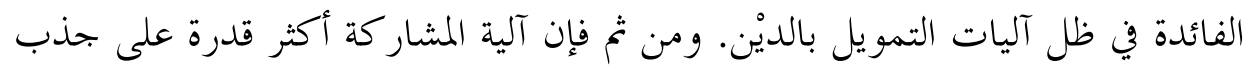

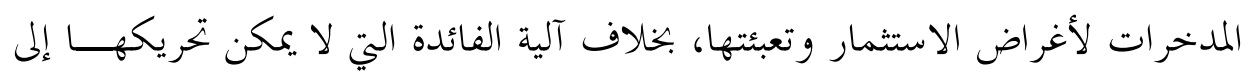
أعلى أو إلى أسفل .كمرونة كافية.

ب. الكفاءة في تخصيص الموارد: ^` المصارف الإسلامية أكثر قدرة على تخصيص الموارد المالية النقدية نحو الاستخدامات الفعلية. و الحقيقة أن المصارف الربوية في ظـلـل

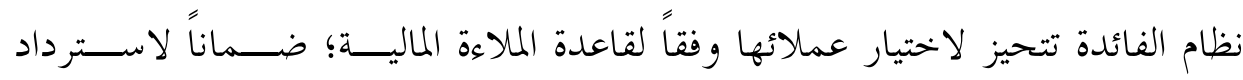

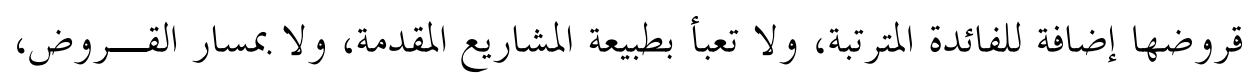
ولا بالمشروع الذي يحقق العوائد العليا من بين المشاريع المقدمة للاقتراض. بل همهـــا الوحيد هو استرداد المال.

وعلاوة على ذلك فإن المصارف الربوية -بناءً على قاعدة الملاءة المالية- تتحيز في توزيع الائتمان لصالح كبار الشركات و العمالاء، ولصالح شركات القطاع العام، على

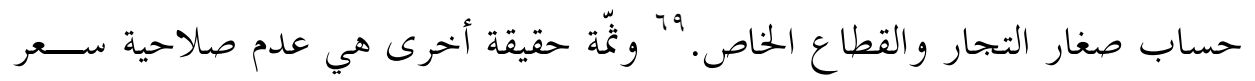

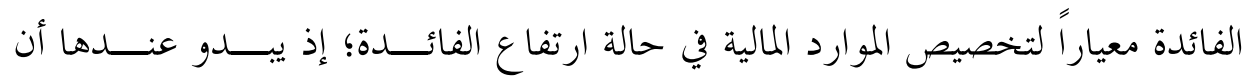
البحالات التي ستستأثر بالأولوية في تخصيص رأس المال في ظل سعر الفائدة المرتفع هي تلك الأنشطة التي تمثل أنشطة ضارة، أو غير منتجة، مثل: بحارة السلاح، و المخدرات، لئات و المضاربات.

وفي المقابل تظهر كفاءة تخصيص الموارد في المصرف الإسلامي في عدم اعتمــاده

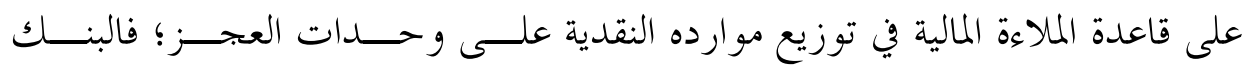

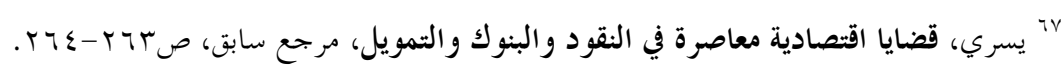

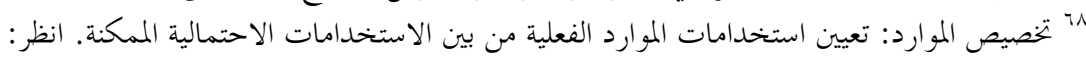

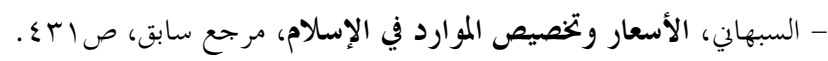

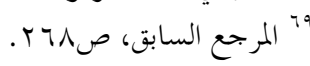

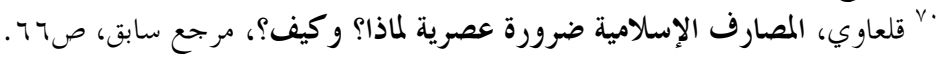




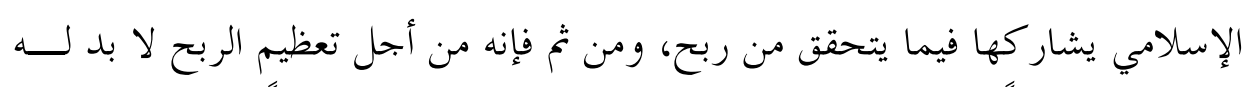

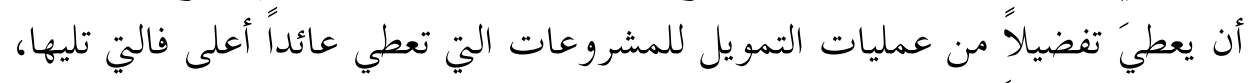

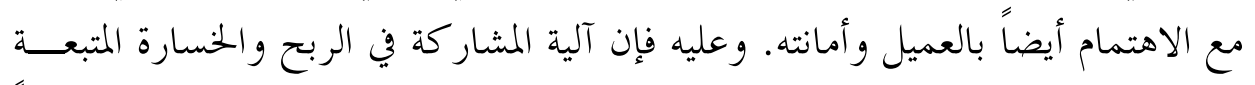

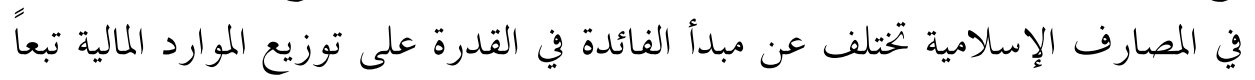

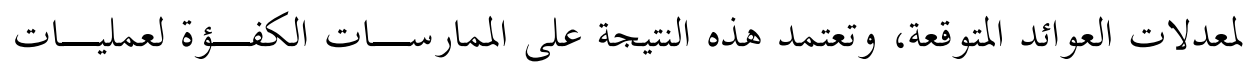

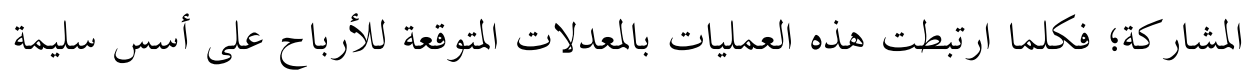
أصبحت أكثر كفاءة، واقتربت من الاستخدام الأمثل لها.

يضاف إلى ما تقدم أنّ معدل العائد على المشاركة غير ثابت زمنياً، وليس واحداً في جميع الأنشطة، وهو بذلك سيعكس حقيقة الحاجة إلى رأس المال (نــــــرة المـــال)

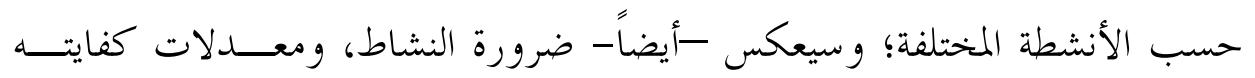
و إنتاجيته، ودر جة المخاطرة فيه، إذ من المتوقع أن تتفاوت حصص رأس المال حســبـ المبـ

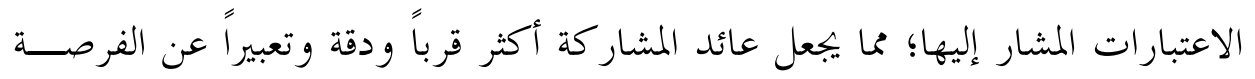

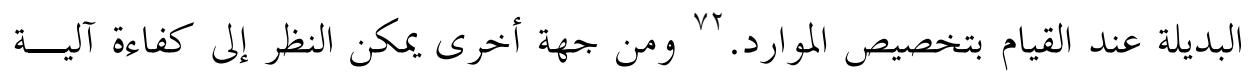

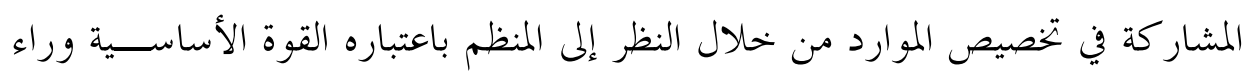

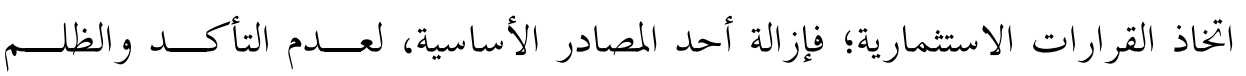
(الفائدة)، يؤدي إلى أثز إيجابي في اتخاذه لقراره. وعلاوة على ذلك فإِاه بتعل المدخرين و المصارف معنيين بنجاح بحارة المنظم؛ بما يؤدي إلى تحسين توافر المعلومات و المهارات و الكفاءة والربحية بما يكفل التخصيص الأمثل للموارد.

وفي الختام يمكن القول -نتيجة لدور المصارف الاجتماعي- إنّ المصرف الإسلامي

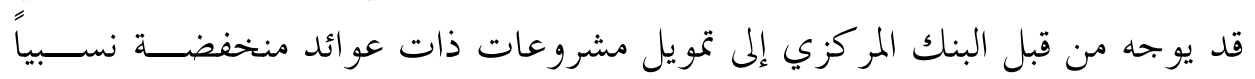

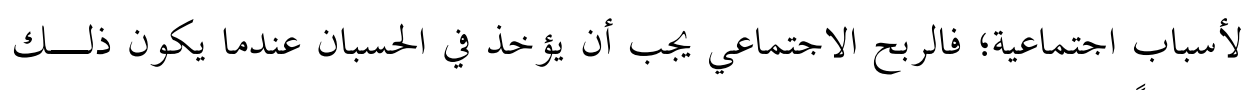
ضرورياً.

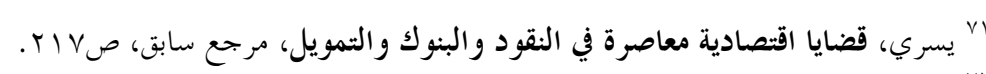

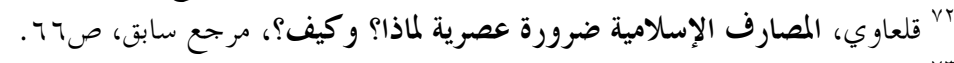

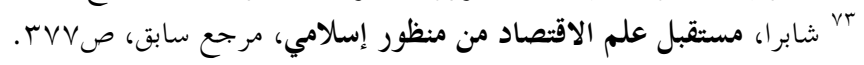




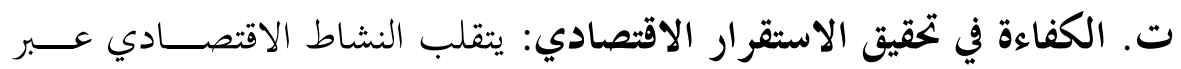

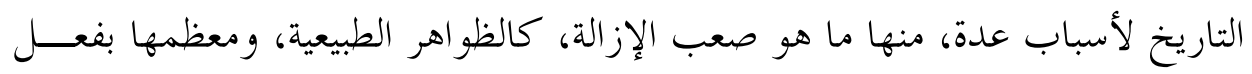

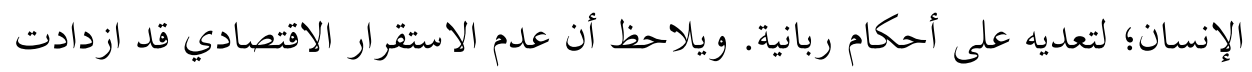

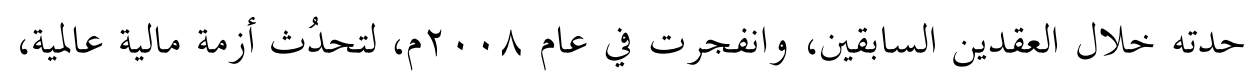

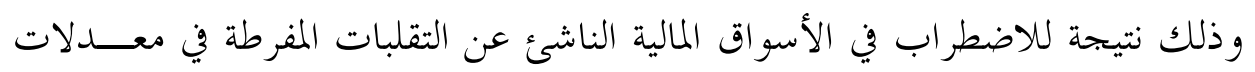

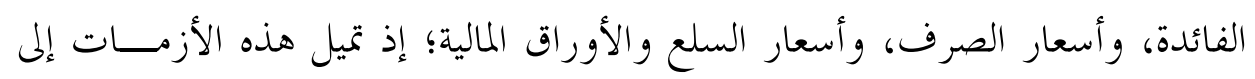

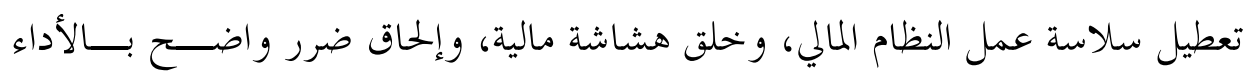

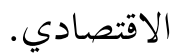

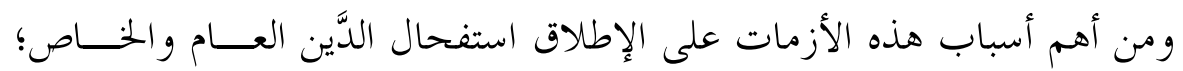

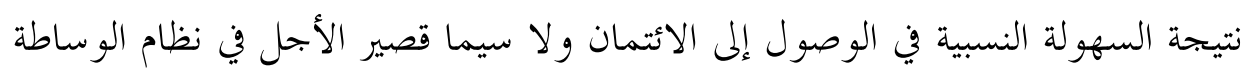

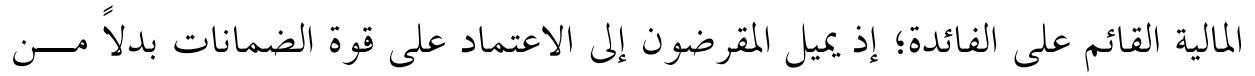

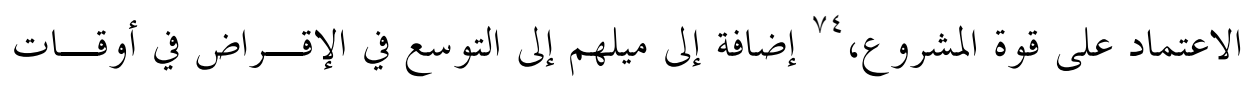

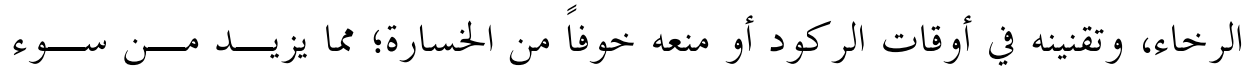

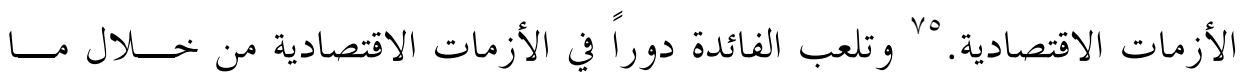

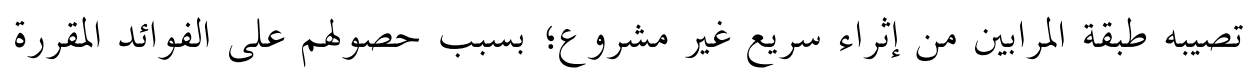
دون المساهمة في مخاطر مشروعاتم. وأشار شابرا في معرض تعليله إلى دور الفائدة في إشعال نار الأزمات بقوله: "يبدو

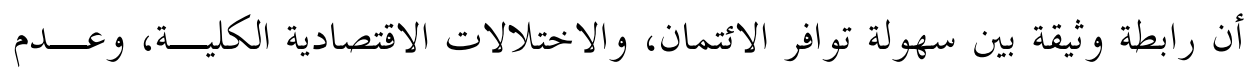

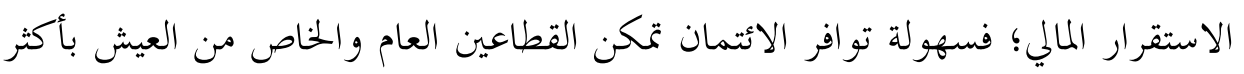

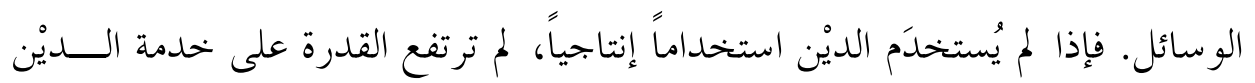

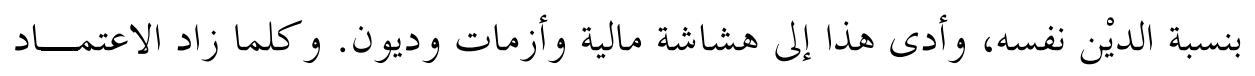

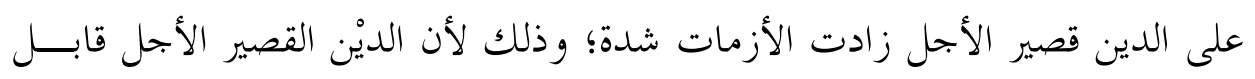

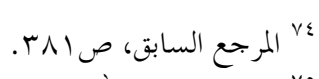

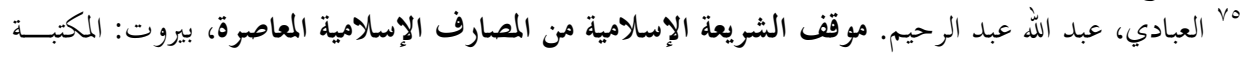

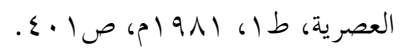




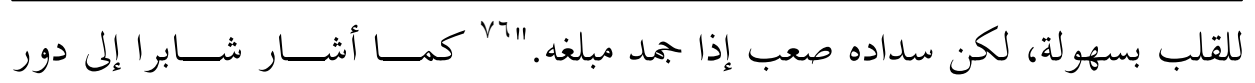
المشار كة في تقليل احتمالية حدوث أزمة مصرفية مالية بقوله: "التحول إلى نظام مـــالي

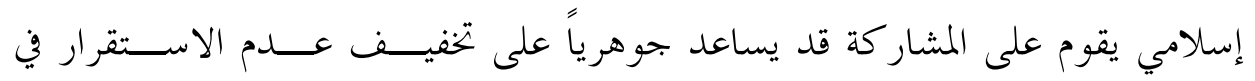

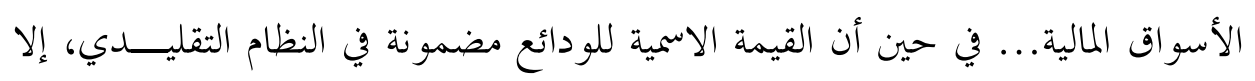

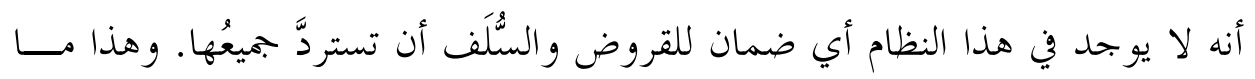
يؤدي إلى وجود تعارض بين الأصول والخصوم، ووفي هاية المطاف إلى أزمة مصرفية إذا

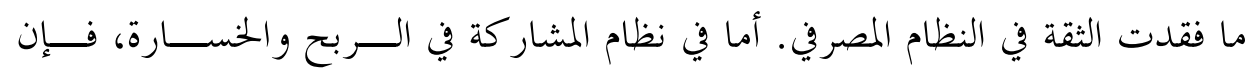

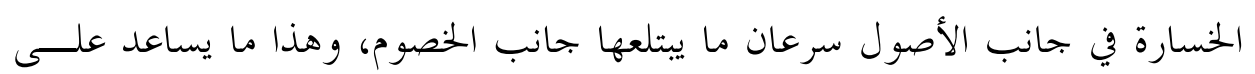

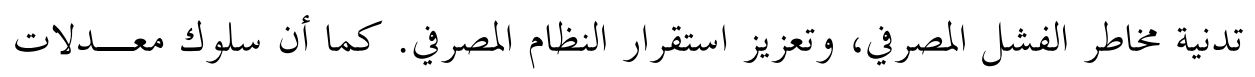

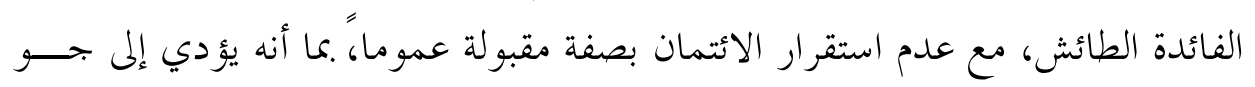

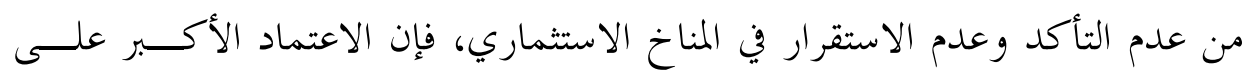

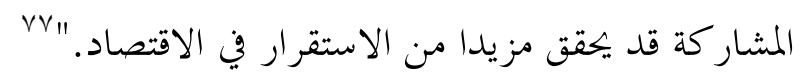

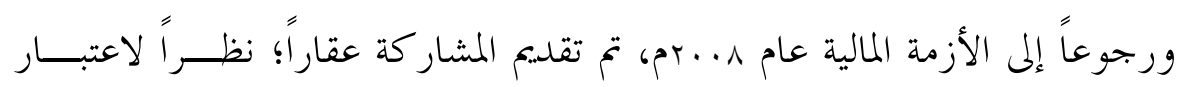

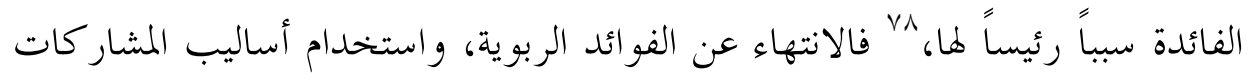

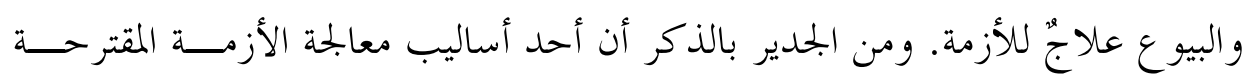

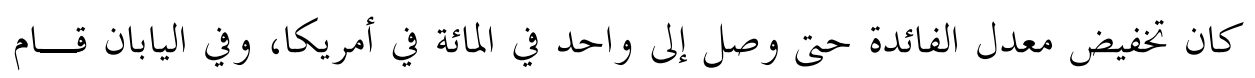
البنك المركزي الياباني بتخفيض سعر الفائدة حتى وصل إلى عشر في المئ والمائة.

لقد أشار كثير من علماء الاقتصاد الوضعي الغربيين إلى دور الفائدة في الأزمات؛

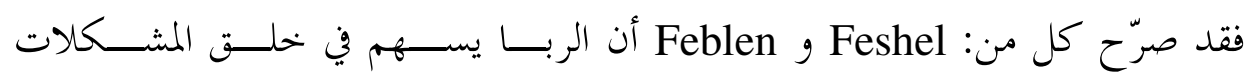

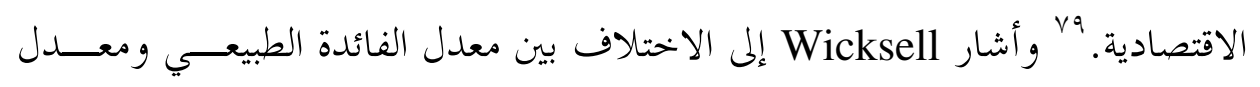

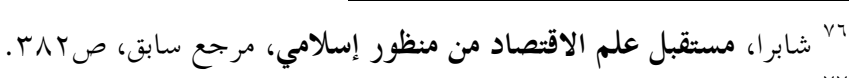

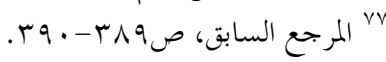

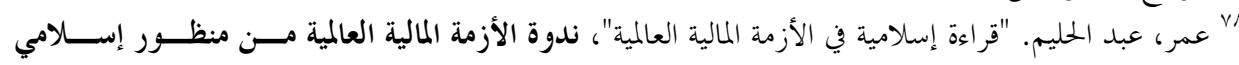

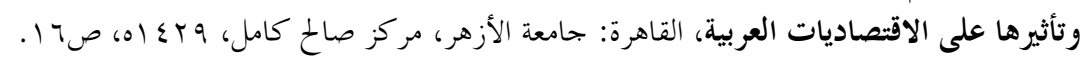

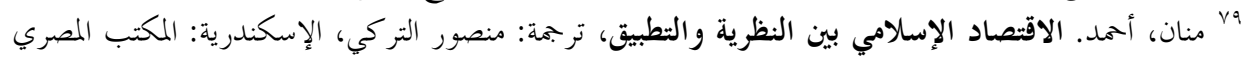


الفائدة النقدي ودوره في إحداث الدورة التجارية، بينما أشار Friedman إلى المــتغير النقدي ودور الاضطراب في تدفقه في تفسير الأزمات الاقتصادية، وما يعنيه ذلك مـــن تر اجع لفرص النمو وتبديد لها. ‘م وقد كتب "Beaufils Vncent" رئيس تحرير بحلة "Challenger" "البابا أو القر آن" يوم السبتمبری . . rم: "أظن أننا بحاجة أكثر في هذه الأزمة إلى قراءة القرآن؛ لفهم ما يحدث بنا و.مصارفنا؛ لأنه لو حاول القائمون على مصارفنا احترام ما

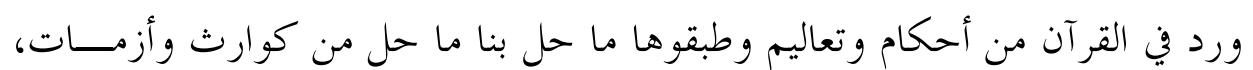

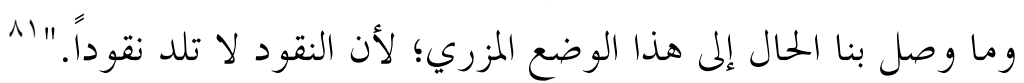
ث. الكفاءة في تحقيق التنمية البشرية: يشكل الإنسان محور الدراسات المتعلقـــة

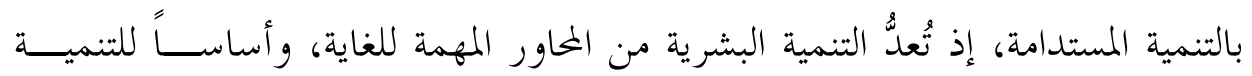

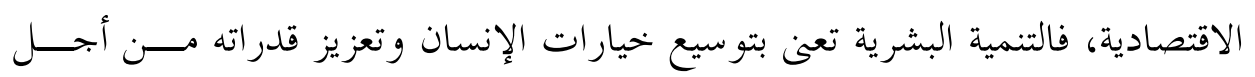
الاستثمار الأمثل، وذلك بإحداث تغيرات هيكلية وجذرية في المورد البشري، وتأهيله وتوجيهه للأفضل، ومن شأن ذلك النهوض بواقع البحتمع الاقتصادي و الاجتماعي. أما فيما يتعلق بدور المصارف الإسلامية عموماً وآلية المشاركة خصوصاً في التنمية

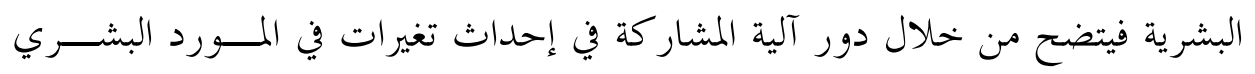

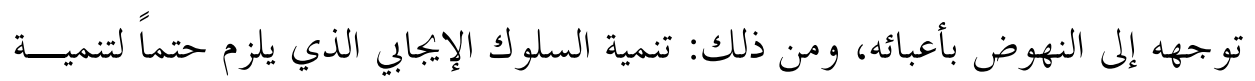

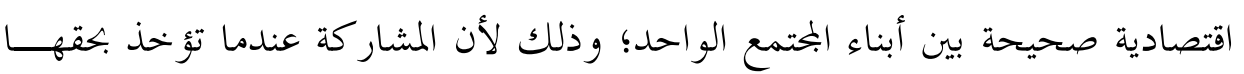

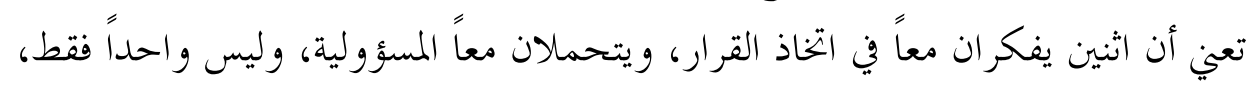
أو بعبارة أخرى: إنّ آلية المشاركة تدفع وحدات الفائض ووحدات النين العجز إلى المساهمة في النشاط الاقتصادي. وذلك في مقابل آليات النظام الربوي القائمة على الفائدة الـــي

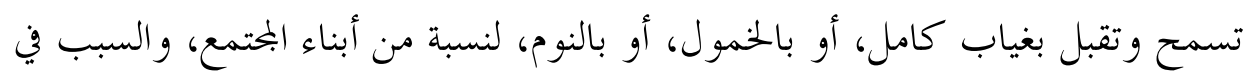

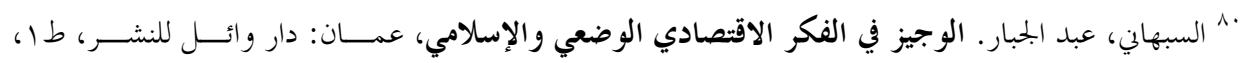

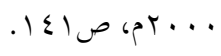

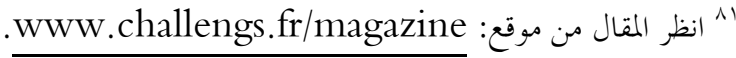


ذلك أهم ادخروا أموالهم، أو ورثوها من غيرهم، أو أهم من الممكن قــــ اكتســـبوها

$$
\text { بطرق غير شرعية. }
$$

و بناء على ما سبق نرى أن العمل المصريف الإسلامي، اعتماداً على مبدأ المشاركة،

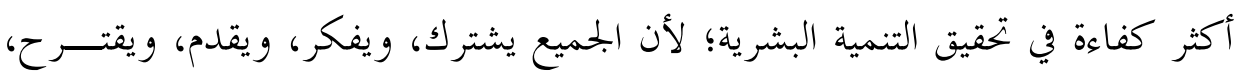

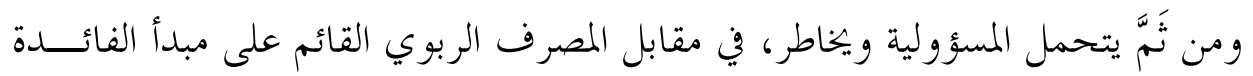

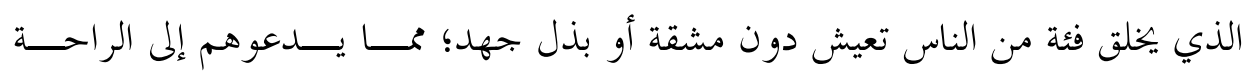
و الركون.

خاتمة:

حاولت في هذا البحث إثبات أنَّ المصارف الإسلامية قادرةٌ على أن تحقق الحلكمة

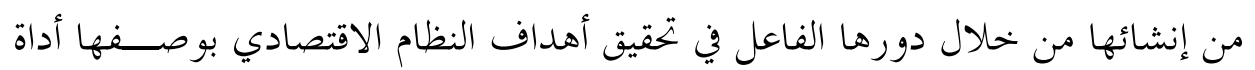

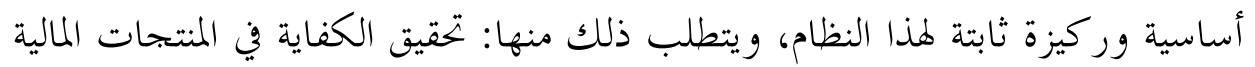

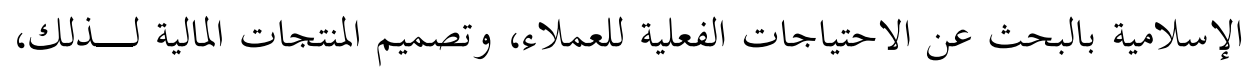

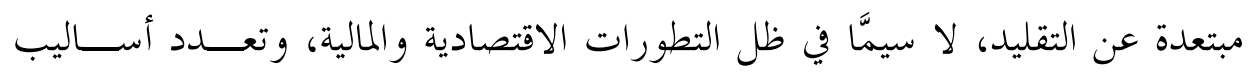

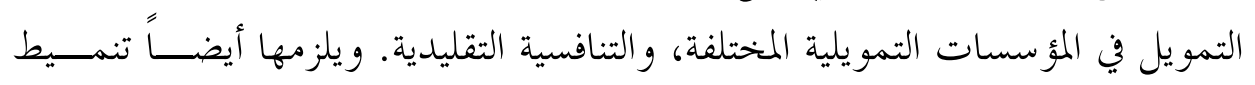

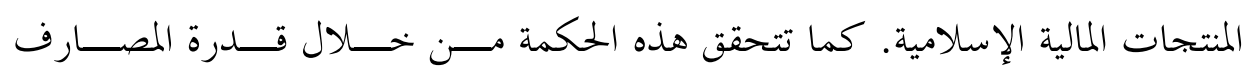

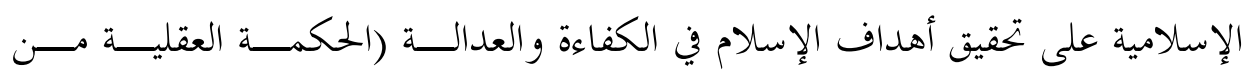

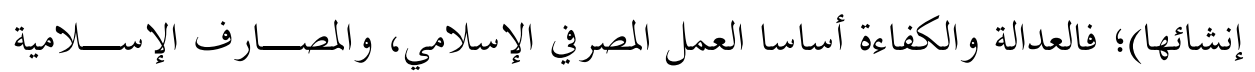

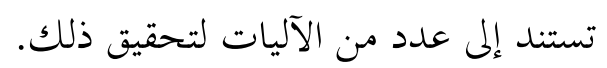

وأظهرت الدراسة أنَّ المصارف الإسلامية ابتعدت عن الحكمة الأساسية للعمــل

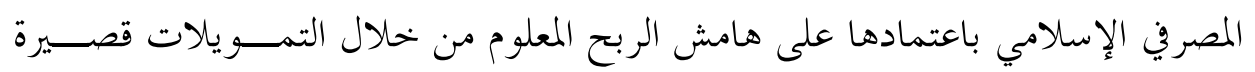

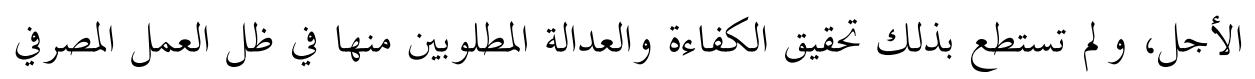

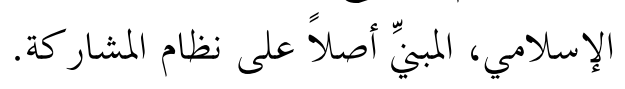

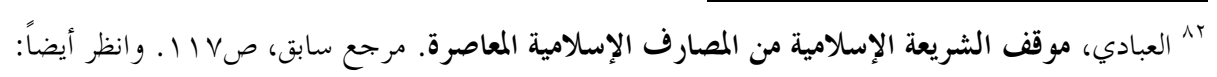

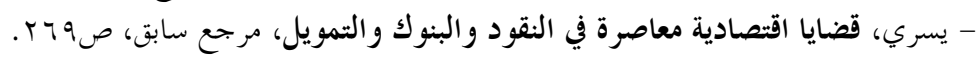




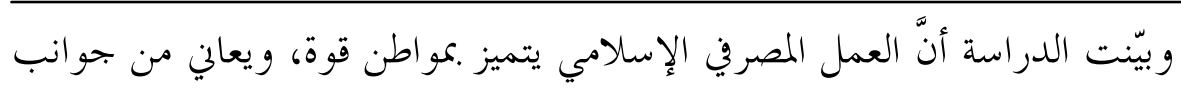

ضعف؛ لكن مواطن القوة في المصارف الإسلامية تتغلب على جوانب الضعف، بدليل الانتشار الدولي و النمو الكبير. و تأتي مواطن القوة من خلال دور المصارف الإسلامية

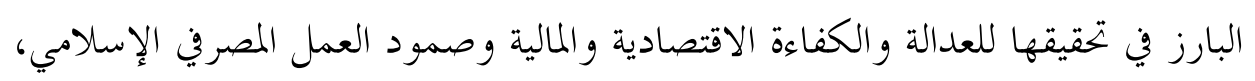
المبني على المشار كة، في وجهه الأزمات.

أما نقاط الضعف التي تعاني منها المصارف الإسلامية فيمكن معالجتها إذا توافرت

النوايا الصادقة، وقد قدمت الحلول المقترحة لمعالجتها.

وتوصي هذه الدراسة المصارف الإسلامية بالعمل على تحقيق الكفاية في المنتجات المالية الإسلامية اعتماداً على الابتكار و التجديد بما يخدم الاحتياجات التمويلية، وابتعاداً

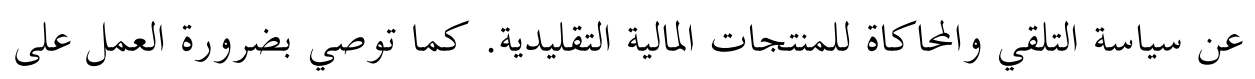

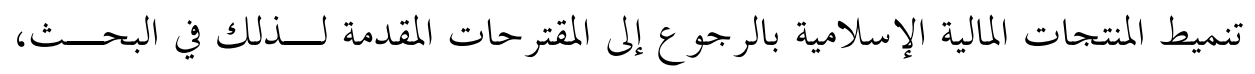

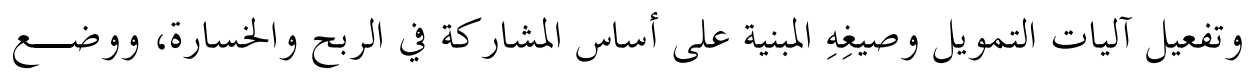

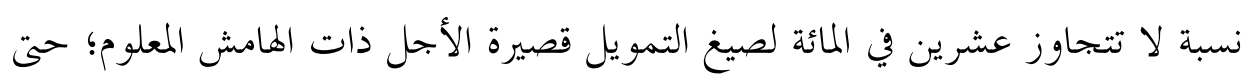

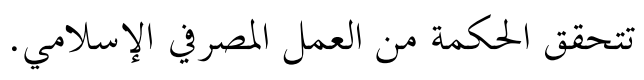

